\title{
The importance of the altricial - precocial spectrum for social complexity in mammals and birds - a review
}

\author{
Isabella B. R. Scheiber ${ }^{1 *}$, Brigitte M. Weiß ${ }^{2,3}$, Sjouke A. Kingma ${ }^{1}$ and Jan Komdeur ${ }^{1}$
}

\begin{abstract}
Various types of long-term stable relationships that individuals uphold, including cooperation and competition between group members, define social complexity in vertebrates. Numerous life history, physiological and cognitive traits have been shown to affect, or to be affected by, such social relationships. As such, differences in developmental modes, i.e. the 'altricial-precocial' spectrum, may play an important role in understanding the interspecific variation in occurrence of social interactions, but to what extent this is the case is unclear because the role of the developmental mode has not been studied directly in across-species studies of sociality. In other words, although there are studies on the effects of developmental mode on brain size, on the effects of brain size on cognition, and on the effects of cognition on social complexity, there are no studies directly investigating the link between developmental mode and social complexity. This is surprising because developmental differences play a significant role in the evolution of, for example, brain size, which is in turn considered an essential building block with respect to social complexity. Here, we compiled an overview of studies on various aspects of the complexity of social systems in altricial and precocial mammals and birds. Although systematic studies are scarce and do not allow for a quantitative comparison, we show that several forms of social relationships and cognitive abilities occur in species along the entire developmental spectrum. Based on the existing evidence it seems that differences in developmental modes play a minor role in whether or not individuals or species are able to meet the cognitive capabilities and requirements for maintaining complex social relationships. Given the scarcity of comparative studies and potential subtle differences, however, we suggest that future studies should consider developmental differences to determine whether our finding is general or whether some of the vast variation in social complexity across species can be explained by developmental mode. This would allow a more detailed assessment of the relative importance of developmental mode in the evolution of vertebrate social systems.
\end{abstract}

Keywords: Altricial-precocial spectrum, Birds, Mammals, Social behaviour, Social cognition

\section{Background}

Studies that investigate vertebrate social life from various perspectives (i.e. behavioural, neurobiological, physiological and cognitive components) are on the leading edge of scientific investigations both from an evolutionary and mechanistic point of view (e.g. [1-7]). The general characteristic that defines complex social systems in vertebrates is that animals live in long-term stable groups of multiple

\footnotetext{
* Correspondence: isabella_scheiber@t-online.de

${ }^{1}$ The University of Groningen, Behavioural and Physiological Ecology, Groningen Institute for Evolutionary Life Sciences (GELIFES), Nijenborgh 7, 9747 AG Groningen, The Netherlands

Full list of author information is available at the end of the article
}

generations, which allows for repeated interactions with differently familiar individuals. These interactions encompass various forms of cooperation and competition over resources, and require considerable learning over the course of development [8]. As such, various factors, including life history, physiology and brain structure, which may be associated with potential differences in cognitive abilities, shape individuals' engagement in complex social interactions.

One often-neglected feature that may underlie variation in the complexity of social systems is a differentiation of species with respect to their developmental mode, i.e. the 'altricial-precocial' spectrum. Based on inferences from indirect factors such as life history and brain size, several 
authors have recently hinted at a connection between developmental modes, brain size and variation in the complexity of social life, bonding systems and cognition (e.g. [4, 6, 7, 9-17]). From a mechanistic point of view, such a pathway from developmental mode to social complexity seems plausible (see Fig. 1, "conventional view"), but the explicit relationship between developmental mode and social complexity has received limited attention. Accordingly, we do not know if evolutionary history of social complexity supports this link nor, if it exists, the causality between developmental mode and social complexity. One of our aims here is to survey the existing literature to determine whether social complexity is related to variation in developmental mode in mammals and birds, the two most extensively studied vertebrate taxa in this regard.

The alterations in brain size with an alleged impact on cognitive abilities in species along the altricial-precocial spectrum have led to the prevalent notion that largerbrained species also have a more complex social life (e.g. $[4-6,18])$. Alternatively, there is recent debate on whether complex social life - indeed - requires large brains and highly complex cognitive skills or whether similarly complex sociality can be attained through variation in brain composition (i.e. 'cerebrotypes, see below) and/ or simpler cognitive mechanisms (e.g. $[1,7,19-21])$. This dichotomy in thinking requires a thorough assessment, which we

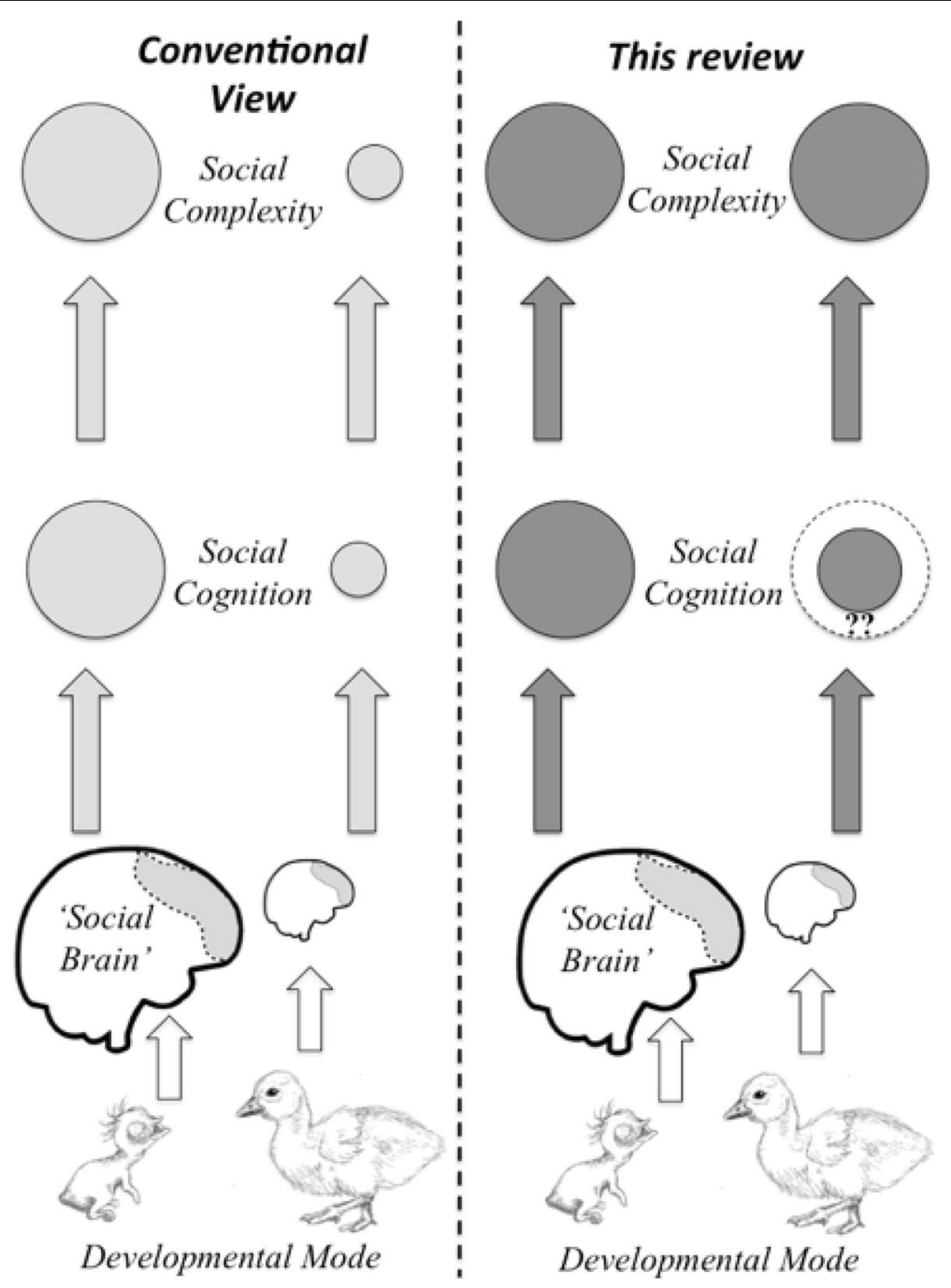

Fig. 1 Schematic representation of the relationship between developmental mode [altricial offspring left, precocial offspring right], social brain size, social cognition and social complexity. Whereas the influence of developmental mode on variation in the 'social brain size' and ensuing cognitive abilities and the deduced effects on social complexity are well established (conventional view, light grey pathway; (e.g. [4, 6, 9-12, 14, 15, 17]), we emphasize a different idea in this review, namely that social complexity may not be associated with developmental mode despite differences in brain size (dark grey pathway; see Table 1). Whether socio-cognitive skills are similar or reduced in precocial and altricial species, however, cannot be determined due to the lack of systematic studies addressing these questions (Displayed by '??' as well as a dashed circle of social cognition in the right pathway) 
provide in this review. Our expectation is that complex social systems can similarly be found in birds and mammals regardless of their developmental mode as complex social behaviour is found throughout the entire animal kingdom. Therefore, we will evaluate, whether social behaviours are expressed similarly or differently in precocial and altricial species. We aim to assess whether the inferred indirect link of a relationship between developmental mode and social complexity via variation in relative brain size is supported or if there is a direct link between developmental mode and social complexity independent of brain size variations (Fig. 1). In this context, we will focus on similarities and differences of the 'social brain', as it is now clear that the brain circuits which regulate social behaviour in non-mammalian vertebrates are homologous to those found in mammals [22-25]. We will also summarize the ongoing debate about whether coping in a social world requires high-level cognition $[1,7,16,21]$ and how variation in developmental modes affects cognitive abilities.

\section{The altricial precocial spectrum in mammals and birds}

The altricial-precocial spectrum describes the degree of behavioural and morphological maturation of offspring at the moment of birth or hatching [26]. In precocial species, young require limited parental care and are relatively mature, mobile and can either mainly feed self-sufficiently (precocial birds) or forage independently from early on while still being nursed (precocial mammals). Altricial young, in contrast, are initially incapable of moving around on their own and require extensive parental care, like brooding or food provisioning. The most extreme developmental modes are super-precociality, where offspring are completely independent immediately after hatching or birth (as in e.g. megapodes, black-headed duck or wildebeest [27-29]), or super-altriciality, where offspring hatch or are born more or less naked with their eyes closed (as in e.g. cricetid rodents, canids [30], monotremes [31] and marsupials [14, 32, 33], passerines or parrots [for review [34]). A recent re-evaluation of the altricial-precocial classification of species by Ligon \& Burt [35] denominated 8890 species out of the 9993 extant species of birds to have altricial development [36]. The distribution of developmental modes in the \pm 5420 mammal species is not as straightforward [30], but seems to be correlated with body size or mass, gestation period, and/or number of offspring: larger mammals are more likely to produce very few precocial young per litter [30, 37-40] whereas small mammals are more likely altricial and produce more young. One notable exception, amongst others, are bats (Chiroptera), which presumably produce small altricial litters due to adaptation for flight [41]. Starck \& Ricklefs [26] provide a detailed summary on the evolutionary diversification of life histories in relation to the marked variation in development mode, parental care and rate of growth in primarily birds, with a short section devoted to mammals. It is now well established that these different developmental trajectories have long-term consequences in various aspects of endocrine, reproductive or other physiological mechanisms. In this review, we will, therefore, focus on another feature, i.e. the influence of developmental modes on the complexity of social systems and its underlying mechanisms only. We focus on several important social and cognitive features (see Table 1; detailed below) that we deem essential for complex sociality, to determine if these can be found in avian and mammalian species along the altricial-precocial spectrum. As there is only a very limited number of studies available that specifically incorporate the developmental mode in questions pertaining to complex sociality, and because social complexity is difficult to comparably quantify (but see [42] for a recent review and new definition), we were unable to perform a rigid meta-analysis. Specifically, we first summarise the possible features that we assume reflect social complexity. Second, we describe the cognitive features that are considered to be necessary in order to establish, maintain and manage complex social relationships. Finally, we compiled a thorough collection of studies connecting developmental mode with 15 different features of social complexity, including social (e.g. affiliative behaviour or long-term bonds) and cognitive (e.g. kin recognition) features of altricial and precocial mammals and birds (see Tables 1 and 2 for definitions of the features used in this review).

\section{Arguments for and against linking social complexity with developmental mode}

There are recent claims that the manner and quality of social relationships depends on the developmental mode $[5,6,10,17,43]$ due to the link of developmental mode and brain development. In mammals, expansion of the cerebral cortex plays a major role in managing social interactions, whereas in birds and seemingly socially complex marsupials, social interactions are regulated by the homologous enlarged telencephalon [43-46], but with keeping in mind that hardly any information on the social system of marsupials is available. The general pattern in birds is that adults in altricial species have relatively large brains compared to adults of precocial species, whereas at hatching the pattern is reversed $[47,48]$. Precocial offspring possess relatively large brains due to the fact that neural growth in precocial species takes place in the egg, while in altricial species it occurs after hatching ([47] for review). Due to their extended post-hatching development, altricial bird species might therefore be more skilled in managing social interactions given their larger brains. On the other hand, relative brain size in mammals does not seem to be correlated with developmental mode per se [49], but rather is negatively correlated with litter size in altricial species and a 


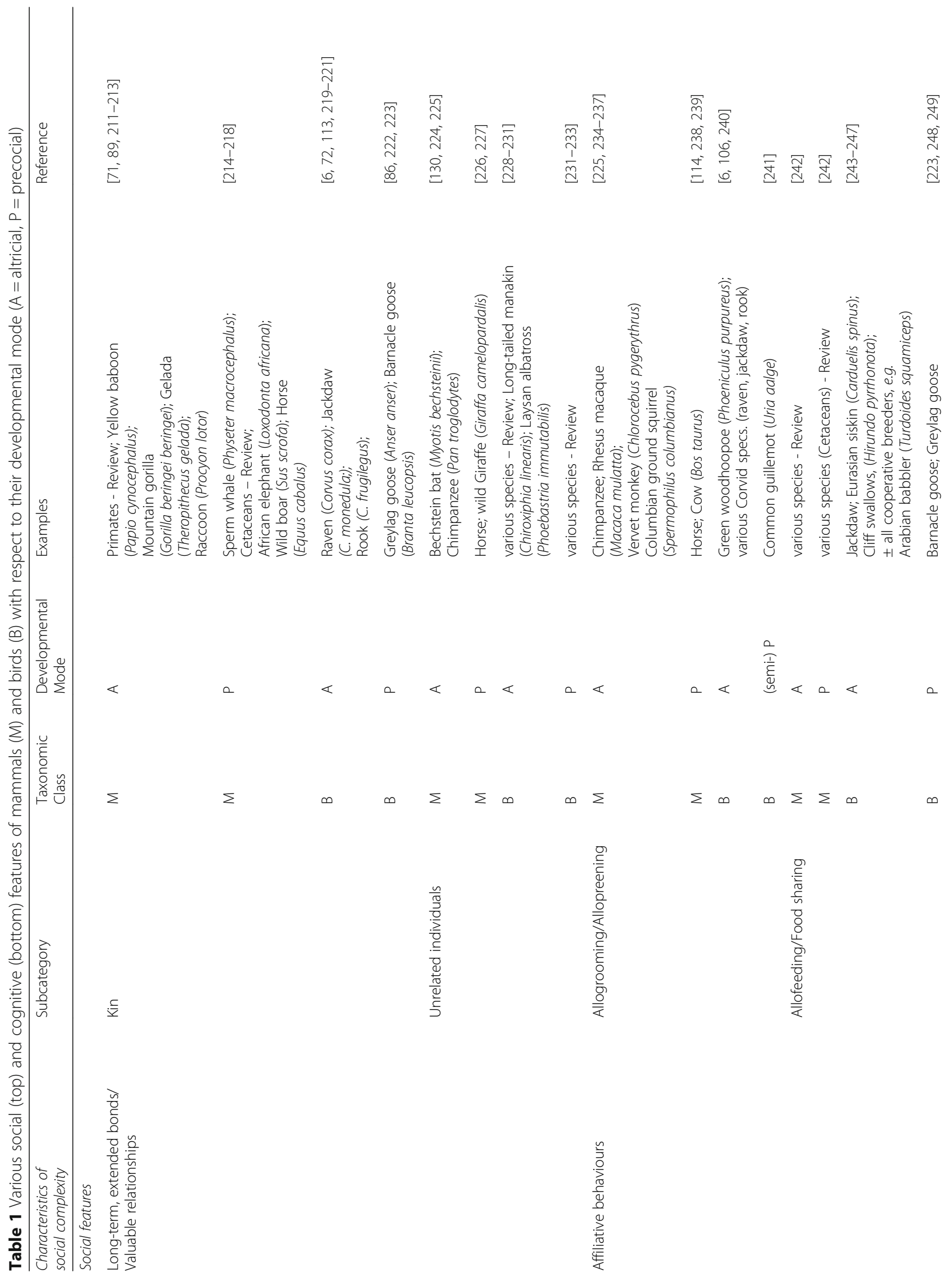




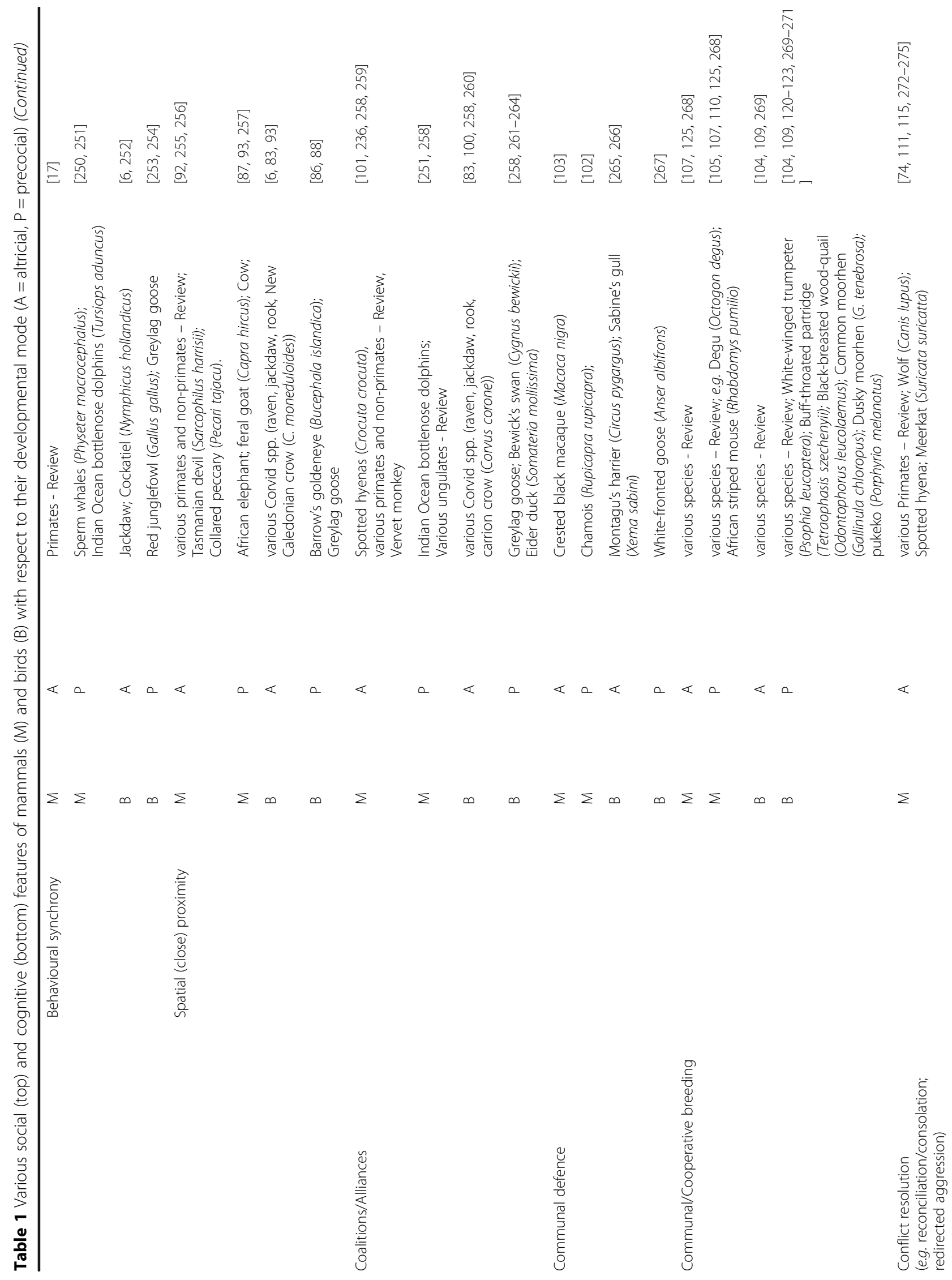




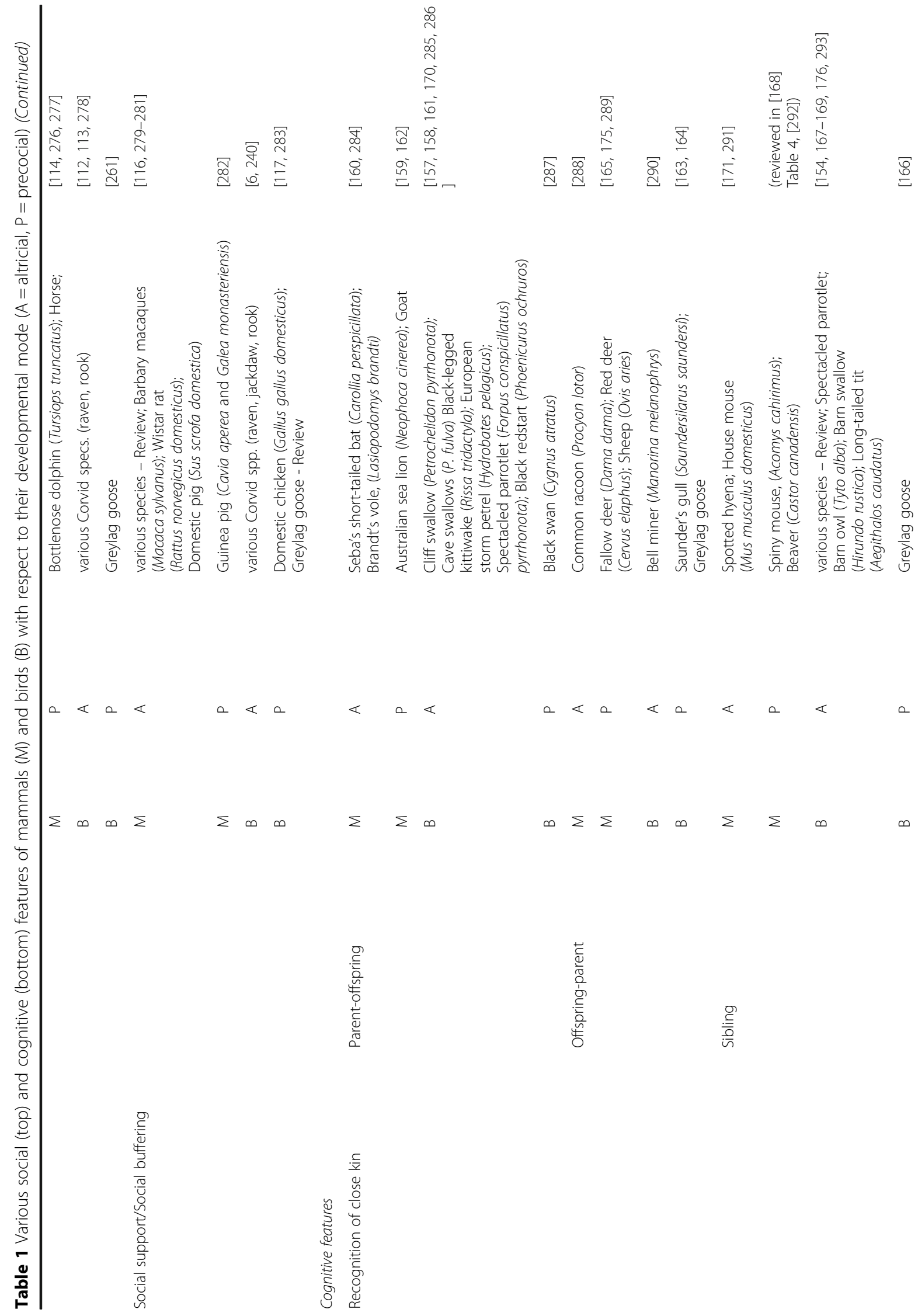


Scheiber et al. Frontiers in Zoology (2017) 14:3

Page 7 of 20

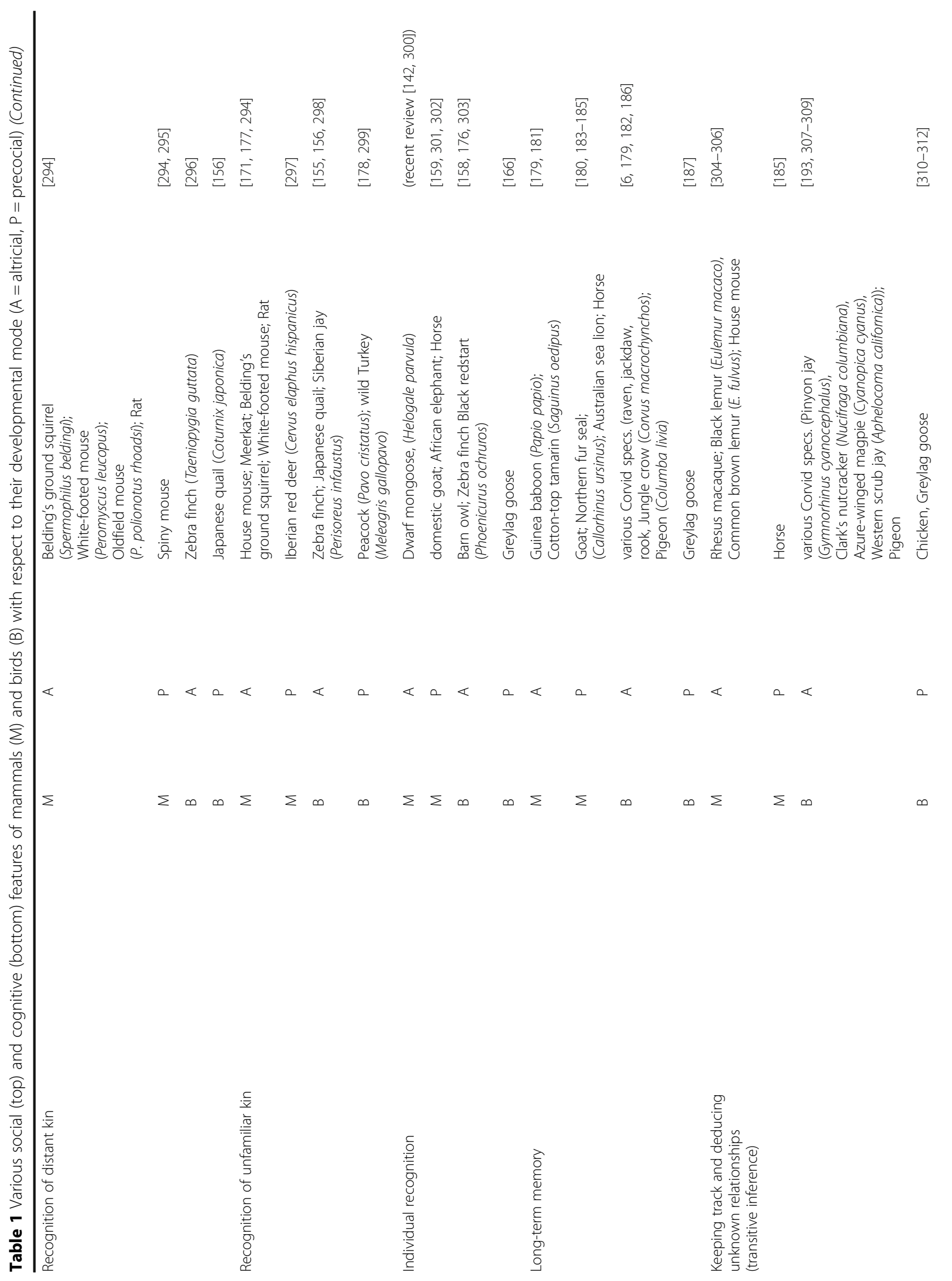




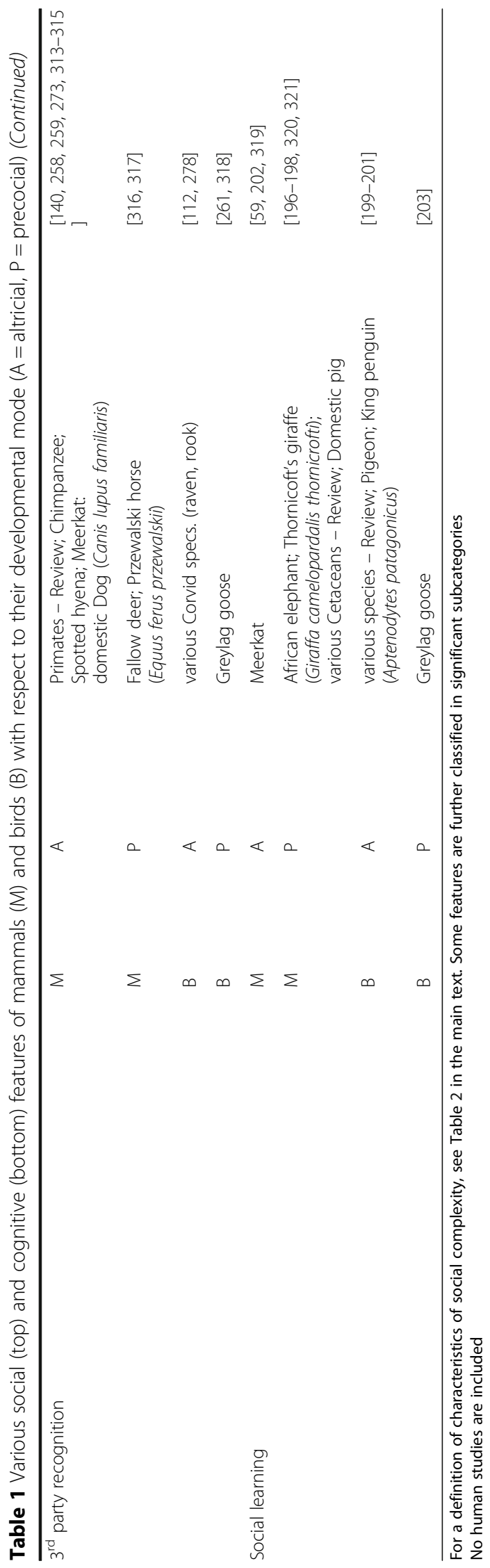




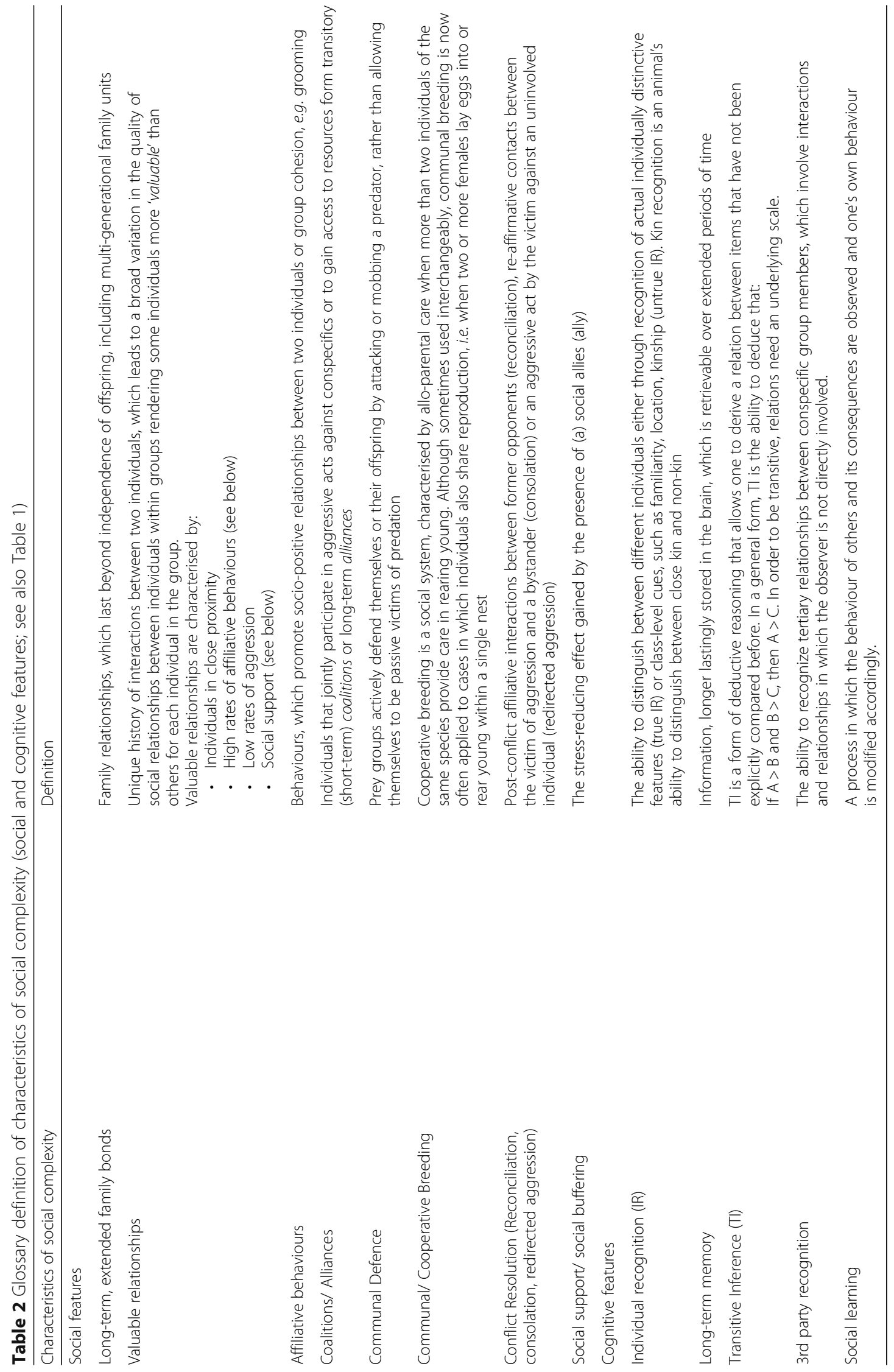


reduction in birth rate in precocial species ([14] for review, $[50,51])$. The proposed explanation for this pattern is that precocial mammals develop slower and reach sexual maturation later in life than altricial young [51].

Arguments against a relationship between social complexity, brain size variation and developmental mode stem from studies that measured the size of multiple brain regions in a multivariate context in mammals and birds [15, 52-54]. These so-called 'cerebrotypes' are defined by comparing the proportional size of different parts of the brain to total brain size. Developmental mode does not seem to have a strong effect on cerebrotypes, as altricial and precocial species are represented in each avian- $[12,54]$ and mammalian-specific [52] cerebrotype.

Another aspect that supports the notion of similar social complexity in altricial and precocial species are the underlying neuro-endocrinological and molecular mechanisms, which play a central role in the regulation of maternal and other socio-sexual behaviours. These mechanisms involve a range of neuropeptides (e.g. $\beta$ endorphin, corticotrophin-releasing factor, oxytocin and arginine-vasopressin as well as the avian homologues mesotocin and arginine-vasotocin) and are highly conserved throughout vertebrates of all developmental modes [30, 55-58]. Oxytocin mediates several forms of affiliative behaviours, including parental care, and grooming $[3,59-64]$, the formation of a pair-bond [65, $66]$, as well as the establishment of the exclusive bond between mothers and offspring [67]. Oxytocin is also known for its positive impact on the development of trust and recognition of familiar individuals in rodents [68] and estrildid finches [61]. Likewise, the 'social behaviour network'- brain regions that control social behaviour - is also very highly conserved across the vertebrates $[22,69]$ irrespective of developmental mode. Precocial and altricial species thus possess a similar neuro-endocrinological tool kit, which is an essential prerequisite for acquiring similarly complex social behaviour. In the following sections, we will review to what extent these similarities and differences in brain structures and physiology translate into similarities or differences in social complexity and cognition.

\section{Compilation of data}

We collected data for this review searching the Web of Science to find publications whose title, abstract or key words included any of the following terms: developmental mode/ altricial/ precocial, social system/ social complexity, mammal, bird. We omitted any studies, in which developmental mode and sociality were not defined in the main text. We double-checked information on every publication that seemed suitable for this review, by searching the web for additional information on the correctness of developmental mode and social system on any species given, and excluded species in which these issues were equivocal. We then searched the remaining publications for terms characterizing either social complexity or cognitive features (see Table 2) and compiled relevant publications in Table 1 . Whenever possible, we cited published reviews, which contain a wealth of information on various taxa. Finally, we specifically searched for information about social and cognitive features still missing from the table to fill in any missing table cells. In cases where many studies pertained to one topic, we did not list all studies but listed a diverse array of species showing this specific characteristic. Note therefore that our list of species is not exhaustive.

\section{Comparing features of social complexity and elaborate social relationships in precocial and altricial species}

In vertebrates, the complexity of social systems is not related to the actual number of individuals per group, but rather to the variety of associations and elaborate interactions that group members engage in [70] or, as Bergman \& Beehner [42] recently termed it 'the number of differentiated relationships'. It is described best by the maintenance of individualized long-term, mutual, dyadic 'valuable relationships' (sensu [71]). Valuable relationships are characterised by close proximity between bonded partners, the provision of social support, low rates of aggression and the occurrence of affiliative behaviours, particularly also after conflicts have occurred [71]. Hence, for a comparative study, a pivotal question to assess social complexity is how to measure the strength and/or quality of bonds between individuals $[17,72-74]$, as not all measures are comparable or, perhaps, of equal importance across species. Therefore, it is especially important to assess a suite of features that may reflect social complexity to make broad inferences about the role of certain factors in explaining that complexity [42]. For example, certain affiliative tactile behaviours, such as feeding or grooming others, are often used as indicators of close bonds between individuals and are expressed similarly in altricial and precocial mammals [75], but are, in contrast to altricial birds, uncommon or absent in many precocial birds [76]. However, both altricial and precocial species express social bonds in a variety of other ways, including vocal and visual displays ([76-81] for a mammalian review) and chemical [82] cues, increased tolerance and spatial proximity [83-85]. In particular, the spatial association between individuals is often used as a proxy for determining social relationships ([86-88], but see [89]). As such, it is now evident from social network analyses $[90,91]$ that close proximity indeed is a legitimate measure for close affiliative bonds ([92-95], but see [96]). Nearness between individuals that maintain social bonds 
is found in species of all developmental modes (Table 1). In sum, both altricial and precocial birds and mammals resort to a large variety of displaying affiliative bonds. The lack of any one of these above indicators of social bonds, however, does not necessarily infer weak and/or low quality affiliative relationships between precocial or altricial mammals or birds, since other forms of expressing relationships may be in place [85].

Valuable relationships may occur among pair partners, direct family members or distantly related kin $[86,97,98]$ as well as between unrelated individuals [71,99] and may involve coalition and alliance formation [100, 101], communal defence [102, 103], communal or cooperative breeding [98, 104-110], conflict resolution [74, 111-115], and social support $([116,117]$ and references therein) (see Table 1 for a complete overview). We found support for all these aspects in both altricial and precocial mammals and birds (Table 1). However, whether they occur equally frequently among altricial and precocial species cannot be determined from the available literature.

One notable exception where detailed information on the actual distribution in relation to developmental mode is available is cooperative breeding in birds. Cooperative breeding systems are more common in altricial $(11 \%$ of 7698 species, including many passerines) than in precocial (4\% of 789 species) birds $[35,104,118]$. This is presumably due to the extended need of parental care in altricial nestlings, offering the opportunity for subordinates to increase reproductive success of the breeders through helping $([36,119]$, but see [120-123] for examples of cooperative breeding in precocial birds). Although there are several precocial bird species that breed cooperatively, there is a lack of information on their detailed social structure. The only two cases in which we found thorough information, i.e. the white-winged trumpeters (Psophia leucoptera) and dusky moorhen (Gallinula tenebrosa), indicate a polyandrous mating system [122-124]. The malebiased sex ratio in these groups is either due to defence of large permanent territories in order to supply sufficient resources [124], or limited numbers of nest sites [123], which created opportunities for cooperative breeding. In contrast, cooperative breeding in mammals is generally rare $(<5 \%$ species; [125]) and where it does occur, cooperative breeding appears to be independent of the developmental mode [125]. The classic example is probably found in mole rats (rodent infraorder Hystricognathi), which contain solitary, social and a minimum of two eusocial taxa [126]. In the eusocial species, the Damara mole rat (Fukomys damarensis) gives birth to precocial young [127], whereas offspring of the naked mole rat (Heterocephalus glaber) have been described as altricial [128]. Overall, the independence of developmental mode in cooperatively breeding mammals is presumably due to the fact that precocial offspring in mammals (in contrast to birds) still need substantial parental care (e.g. nursing). Thus, extended parental care seems to facilitate cooperative breeding, although the pattern in mammals is less clear than in birds.

Overall, we show that social features are exhibited by both altricial and precocial mammal and bird species. Although differences may exist with regard to cooperative breeding systems, it is likely that this is driven by the greater need for help (e.g. feeding offspring) in altricial compared to precocial species, and that this link is unlikely driven by differences in brain size or the capacity for social complexity [129]. It should be mentioned that there is a dispute on whether cooperative breeding should be considered as socially complex, as generally cooperative breeders possess a more stable group composition than fission-fusion societies [130]. This is supported by the idea of Isler \& van Schaik [51], who suggest that cooperative breeding in mammals seems independent of advanced cognitive abilities, but that an evolutionary change towards allo-parental care might be a precursor for enlargement of the brain. Still, cooperative breeding requires managing social relationships, although social life may require different skills in various social systems. For cooperative breeders, this includes, for example, the ability to recognise group members, dominance, or kin. Furthermore, even if there might be more complex social systems, cooperative breeding warrants a discussion in this review, as it is the social system with the most detailed information on its distribution in relation to developmental mode.

\section{Comparing features of social cognition in precocial and altricial species}

Social life may require a need to anticipate, appropriately respond to, cooperate with, or manipulate the behaviour of others. Consequently, behavioural flexibility and some essential cognitive skills are vital (see [131] for a recent review). Accordingly, being part of a complex social environment has frequently been assumed to require highlevel cognitive skills and a large brain $[4,15,18,43,132-$ 134], although this relationship may not be as firm as suggested. Larger brains certainly are bigger associative tools with a greater capacity to engage in pattern-recognition and completion, but this does not need to be 'cognitive' as usually interpreted. Being longer-lived and more socially complex may require superior pattern-recognition skills as there will be more patterns to be recognised. Accordingly, longer-lived and more socially complex animals will be exposed to larger variability and unpredictability over the course of their life, but this is something different from the kinds of 'cognitive skills' that are conventionally given emphasis to and may be achieved not (only) via brain size but also neuronal circuitry. In precocial primates, for example, cooperatively breeding Callitrichidae (marmosets 
and tamarins) outperform their closest relatives, independently breeding squirrel- and capuchin-monkeys (Cebidae), in socio- but not non-socio cognitive contexts [135] despite the fact that they possess relatively small brains $[136,137]$. Similarly, the lack of a relationship between cooperative breeding and relative brain size in the parvorder Corvida [138] argues against such a link. In neither example, however, can we deduce the influence of developmental mode on social cognition as all representatives of the Corvida are altricial and all representatives of the Callitrichidae are precocial, and comparable data for closely related species that display the opposite developmental mode are not available.

The view that birds are incapable of complex cognitive tasks due to their mainly striatal forebrain has been outdated since it is now clear that the brain circuits, which regulate social behaviour in non-mammalian vertebrates, are homologous to those found in mammals [22-25]. As the 'social brain' hypothesis [4] posits that social complexity and brain size go hand in hand, the developmental mode may, therefore, affect social complexity, particularly in birds. However, the view that complex social interactions indeed require a large brain has recently been challenged $[1,7,16,21,46]$, which may imply that the relationship between social complexity and developmental mode is less clear as well (see Fig. 1). Social behaviour, which appears cognitively demanding [139], might be achieved through simpler associative mechanisms [21, 140], or probably through a combination of associative learning and more cognitively complex explanations. Furthermore, complex behaviour has been suggested to emerge even from relatively simple nervous systems, and to be the product of not only processes occurring in the brain but of the entire body and the environment [141]. We now will present examples of cognitive abilities we deem crucial for navigating efficiently in a social world, thereby, again, distinguishing between altricial and precocial mammals and birds. Notably, we consider abilities as cognitive irrespective of whether they are presumably simple or complex, following the definition of Shettleworth (pg. 4 [140]) describing cognition as "the mechanisms by which animals acquire, process, store and act on information from the environment ", which therefore comprises perception, learning, memory, and decision-making.

\section{Recognizing others}

Probably the most vital prerequisite of social complexity is the ability of individuals to recognise others, particularly where multiple individuals with differing intentions interact with one another repeatedly. Such social recognition is an underlying assumption of behaviours including nepotism ([142] for review), several forms of cooperation [143, $144]$, deception $[145,146]$ or direct reciprocity $[144,147]$. Once again, there is an ongoing debate as to whether the ability to recognise others is cognitively demanding, as it can either be achieved through cognitively simpler means, such as differentiating between more or less familiar individuals ('class level recognition' ([148], but see [149]), or through recognition of unique individual features (true individual recognition), which is thought to require specific cognitive adaptations [150]. As both class level recognition or true individual recognition involve cues produced by the signaller as well as perception by the receiver and a specific behavioural response [149], we consider both to require cognitive skills albeit variation in the degree of complexity.

Kin recognition is important for the evolution of social behaviour in many species [151], as it permits indirect benefits of cooperation when individuals improve fitness of relatives [152,153] or avoidance of kin competition or inbreeding [154-157]. The most commonly studied forms of kin recognition consist of three domains: parentoffspring recognition [158-162], offspring-parent recognition [163-165] and sibling recognition [154, 166-169]. Our survey of the literature indicates that these appear commonly in both precocial and altricial birds and mammals (Table 1). Parent-offspring recognition, based on familiarity or on phenotypic traits, seems to be well developed in cooperative breeders [151, 170-173] presumably because kin-selected benefits often drive the care of others' offspring [174]. Studies on offspring-parent recognition seem to indicate that being able to identify parents is particularly important in precocial species $[26,163$, $175]$, because there is a higher potential to lose contact with the parent if the offspring is not confined to a nursery, e.g. nest or burrow. Sibling recognition has been studied quite intensively and identified in mammals, particularly rodents, and to a lesser extent in both altricial and precocial avian systems ([166, 176], for review [168]). Regardless of developmental mode, some birds and mammals can also recognise unfamiliar kin based on phenotypic traits [155, 156, 177, 178]. Thus, developmental mode in both mammals and birds seems insignificant in the ability to recognise other individuals.

\section{Long-term memory}

Another useful skill of social animals may be the ability to retain information on group members or outcomes of previous interactions over extended periods of time [179]. Although there are not many studies on social memory, those conducted to date seem to indicate that the mode of development has no influence on either the duration that animals may remember socially relevant individuals [180184] or on keeping track of hierarchical relationships [185-187]. In an extensive literature search, we found only one study that specifically compared learning memory and memory retention ('recall memory') in a colour discrimination task in an altricial (domestic Bengalese finch, Lonchura striata domestica) and a precocial (blue- 
breasted quail, Coturnix chinensis)) bird [188]. Recall memory is considered to be more cognitively demanding as it is important to remember attributes or relationships between items, relative to recognition memory, where it is enough simply to remember what was seen before. Quails performed poorly in the learning task and failed in the memory retention task, whereas finches scored more highly in the learning task, and retained the ability to discriminate between colours correctly for 45 days, which suggests an influence of developmental mode [188]. However, as this work was performed with domesticated species, it is difficult to determine if this would also hold true for the closest wild relatives. There is only contradictory information on the social system of closely related Japanese quail (C. japonica) in the wild [189], but the closest relative of the hybridised Bengalese finch, the whiterumped munia (L. striata), is social. The result of the above-mentioned experiment might be a consequence of cognitive skills that are related to sociality, rather than the developmental mode, as, for example, highly social greylag geese (Anser anser) memorise dyadic relationships in a hierarchical colour series for approximately one year [187]. Furthermore, there might be other potential causes for differences in learning memory or memory retention in the two species than developmental mode. For such studies to be conclusive they need to provide a higher number of replicate species, which preferably have a more similar biology. This would allow to isolate the effect of developmental mode from other potential effects on the variable studied.

\section{Remembering and deducing relationships}

In social animals, it may pay to not only identify others but also to understand social relationships between other group members, such as who shares a bond with, or who is related to, whom. There are examples of these 'third party' relationships in altricial and precocial birds and mammals (Table 1), but the limited number of studies does not allow for claims about whether third party recognition is more prevalent in one developmental mode or the other.

Another advantageous skill would be the ability to deduce the nature of unknown relationships from known ones through indirect evidence, a feature known as transitive inference (TI, [190]). Although transitive inference can be useful in various domains, it is particularly beneficial in the context of social dominance, as it may allow individuals to deduce their dominance relationships with other group members without having to interact with each one of them directly. Once thought as a cognitively-demanding feature of logical thinking and reasoning, it is now recognised that transitive inference can also be achieved through relatively simple associative mechanisms ([191] and [192] for reviews) or probably through a combination of both [193, 194].
Transitive inference has been described across a range of taxa, ranging from fish to primates ([195], Table 2), and although it has been described in altricial birds and mammals as well as precocial birds (Table 1), it has not been tested specifically in any precocial mammal. Therefore, overall, we cannot make firm conclusions about the role of the developmental mode in the ability to deduce unknown relationships. However, the available evidence supports the notion that like for earlier-mentioned features, developmental mode seems to play an ancillary role, but we urge future studies to focus on this phenomenon in a wide range of species.

\section{Social learning}

Numerous studies indicate that individuals pay attention to -and learn from- group members [196-203]. Social learning allows for more appropriate responses to environmental or social cues in various contexts in the future. Both social mammals and birds take advantage of the knowledge of others, irrespective of the developmental mode (Table 1). The lack of a thorough differentiation with respect to developmental modes in the context of social learning tactics, however, does not allow for a decisive evaluation of either the frequencies or variation in altricial and precocial species.

\section{Other cognitive skills}

There are several other cognitive skills in the social domain that may be worth investigating with respect to the developmental modes, (e.g. tactical deception [145, 204-208] and other Machiavellian-like behaviours [133, 205, 209]), but we focussed here on the ones we deemed most crucial. As with several of the cognitive skills described above, many of the non-described features have not been studied systematically across the altricial - precocial spectrum, and have been investigated predominantly in 'large-brained' mammals and birds. Therefore, at present, we lack the taxonomic breadth to draw sound conclusions about the influence of the developmental mode on any of the cognitive abilities. This clearly also includes some of the features that are listed in this review.

\section{Conclusion}

Our review of the existing literature shows that many mammal and bird species are skilled in a wide range of contexts in the social domain and the existence of these social skills in both altricial and precocial species suggests that social skills are generally irrespective of species' developmental trajectories. It remains to be investigated if certain aspects of the complexity of various social systems are more common in one developmental mode or the other, and what the evolutionary reason might be. To the best of our knowledge, the only quantitative assessment available is on avian cooperative breeding systems. 
There is a need for explicit comparative investigations on variation of the social features in altricial versus precocial species to unravel similarities or differences in, e.g. the complexity as well as the quality of bonds displayed in these systems. This includes an evaluation of the different types of affiliative behaviours displayed by altricial versus precocial species to determine whether outwardly different behaviours, in fact, signal, for example, similar strengths of social bonds.

Likewise, both altricial and precocial species are proficient in basic abilities of their social cognition despite established differences in brain size. As this has not been studied systematically, it remains to be determined if this is accomplished via the same underlying mechanisms. That we are in need of integrative studies on sociality, cognition and its accompanying communicative skills in order to decipher how the social environment may form behaviour and brain adaptations for social complexity was recently proposed by Sewall (2015) [131]. We suggest adding to this claim also the indispensable needs to take the developmental trajectories into account. The only study to specifically test cognitive abilities in relation to developmental mode [188] was done in only two species of domesticated birds, which may or may not reflect the natural social environment. Studies in closely related altricial and precocial rodents might be especially suitable for a comparative study in this context.

Altogether, from a qualitative point of view there is little reason to assume that the developmental mode affects social complexity or its underlying cognitive capacities. We do, however, need more quantitative and comparative studies on social complexity in altricial and precocial animals. Yet, as Barrett et al. recently stated, "brains evolved as behaviourcontrol systems designed to help animals move around in, and engage actively with the world" [8]. Indeed, despite the well-established variation in brain size and structure, both altricial and precocial species appear to be able to effectively meander through their complex social world [210].

\section{Acknowledgements}

We are grateful to Kate Bebbington for comments and corrections on the manuscript, Louise Barrett, the editor and one anonymous reviewer for helpful suggestions, as well as Stephanie McClelland for drawing an altricial and precocial nestling in Fig. 1, and Rebecca T. Kimball for clarification of some issues with respect to reference number 36 .

\section{Funding}

IBRS was funded by a grant (Dossier Nr. 866.12.406) from the Netherlands Organisation for Scientific Research (NWO, Den Haag, The Netherlands) awarded to J. K and S. A. K. was funded by an NWO Veni fellowship (Dossier Nr. 863.13.017). No funding body had any role in designing the study, collection, analysis or interpretation of the results presented in this review. No funding body participated in writing any portion of this manuscript.

\section{Availability of data and materials}

Data sharing is not applicable for this article as no datasets were generated or analysed during the current study and only published literature is summarised.

\section{Authors' contributions}

IBRS drafted the manuscript. All authors brought expertise to the ideas presented here as well as through the writing of the article. IBRS compiled all references presented in Table 1. All authors read and approved the final manuscript.

\section{Competing interests}

The authors declare that they have no competing interests.

\section{Consent for publication}

We have received consent from Stephanie McClelland via email for publication of the drawing presented in Fig. 1.

\section{Ethics approval and consent to participate}

Not applicable.

\section{Author details}

${ }^{1}$ The University of Groningen, Behavioural and Physiological Ecology, Groningen Institute for Evolutionary Life Sciences (GELIFES), Nijenborgh 7, 9747 AG Groningen, The Netherlands. ${ }^{2}$ Behavioural Ecology Research Group, University of Leipzig, Faculty of Bioscience, Pharmacy and Psychology, Institute of Biology, Talstraße 33, 04103 Leipzig, Germany. ${ }^{3}$ Department of Primatology, Max Planck Institute for Evolutionary Anthropology, Deutscher Platz 6, 04103 Leipzig, Germany.

Received: 27 June 2016 Accepted: 8 December 2016

Published online: 18 January 2017

\section{References}

1. Barrett $L$, Henzi P, Rendall D. Social brains, simple minds? Does social complexity really require cognitive complexity? Philos Trans R Soc B. 2007; 362:561-75.

2. Kappeler PM, Barrett L, Blumstein DT, Clutton-Brock T. Constraints and flexibility in mammalian social behaviour: Introduction and synthesis. Philos Trans R Soc B. 2013;368:20120337.

3. Goodson JL, Thompson RR. Nonapeptide mechanisms of social cognition, behavior and species-specific social systems. Curr Opin Neurobiol. 2010;20: 784-94.

4. Dunbar RIM. The social brain hypothesis. Evol Anthropol. 1998;6:178-90.

5. Shultz S, Dunbar RIM. Social bonds in birds are associated with brain size and contingent on the correlated evolution of life-history and increased parental investment. Biol J Linn Soc. 2010;100:111-23.

6. Emery NJ, Seed AM, von Bayern AMP, Clayton NS. Cognitive adaptations of social bonding in birds. Philos Trans R Soc B. 2007:362:489-505.

7. Holekamp KE. Questioning the social intelligence hypothesis. Trends Cogn Sci. 2007;11:65-9.

8. Barrett L, Henzi SP, Lusseau D. Taking sociality seriously: the structure of multi-dimensional networks as sources of information for individuals. Philos Trans R Soc B. 2012;367:2108-18.

9. Barton RA, Capellini I. Maternal investment, life histories, and the costs of brain growth in mammals. Proc Natl Acad Sci U S A. 2011;108:6169-74.

10. Dunbar RIM, Shultz S. Evolution in the social brain. Science. 2007;317:1344-7.

11. West RJC. The evolution of large brain size in birds is related to social, not genetic, monogamy. Biol J Linn Soc. 2014;111:668-78.

12. Charvet CJ, Striedter GF. Developmental modes and developmental mechanisms can channel brain evolution. Front Neuroanat. 2011;5:1-5.

13. Custer CM, Custer TW, Thyen S, Becker PH. Incubation stage and polychlorinated biphenyl (PCB) congener patterns in an altricial and precocial bird species. Environ Pollut. 2014:195:109-14.

14. Weisbecker V, Goswami A. Neonatal maturity as the key to understanding brain size evolution in homeothermic vertebrates. Bioessays. 2011;33:155-8.

15. Willemet R. Reconsidering the evolution of brain, cognition, and behavior in birds and mammals. Front Psychol. 2013;4:Article 396.

16. Healy SD, Rowe C. A critique of comparative studies of brain size. Proc $R$ Soc B. 2007;274:453-64.

17. Dunbar RIM, Shultz S. Bondedness and sociality. Behaviour. 2010;147:775-803.

18. Perez-Barberia FJ, Shultz S, Dunbar RIM. Evidence for coevolution of sociality and relative brain size in three orders of mammals. Evolution. 2007:61:2811-21.

19. Beauchamp G, Fernandez-Juricic E. Is there a relationship between forebrain size and group size in birds? Evol Ecol Res. 2004:6:833-42.

20. Chittka L, Niven J. Are bigger brains better? Curr Biol. 2009;19:R995-1008. 
21. Heyes C. Simple minds: a qualified defence of associative learning. Philos Trans R Soc B. 2012;367:2695-703.

22. Goodson $\mathrm{J}$. The vertebrate social behavior network: evolutionary themes and variations. Horm Behav. 2005;48:11-22.

23. Jarvis ED. Bird brain: evolution. In: Squire LR, editor. Encyclopedia of neuroscience, vol. 2. Oxford: Oxford Academic Press; 2009. p. 209-15.

24. Jarvis ED, Güntürkün $O$, Bruce L, Csillag A, Karten H, Kuenzel W, Medina L, Paxinos G, Perkel DJ, Shimizu T, et al. Avian brains and a new understanding of vertebrate brain evolution. Nat Rev. 2005;6:151-9.

25. Güntürkün O, Bugnyar T. Cognition without cortex. Trends Cogn Sci. 2016; 20:291-303.

26. Starck JM, Ricklefs RE. Avian growth and development: evolution within the altricial-precocial spectrum. New York: Oxford University Press; 1998.

27. Sinclair ARE, Mduma SAR, Arcese P. What determines phenology and synchrony of ungulate breeding in Serengeti? Ecology. 2000;81:2100-11.

28. Dekker R. Distribution and speciation of megapodes (Megapodiidae) and subsequent development of their breeding. In: Renema W, editor. Biogeography, time, and place: distributions, barriers, and islands. Dordrecht: Springer; 2007. p. 93-102 [Landman NH, Jones D, S. (Series Editor): Topics in Geobiology].

29. Lyon BE, Eadie JM. Patterns of host use by a precocial obligate brood parasite, the black-headed duck: Ecological and evolutionary considerations. Chin Birds. 2013;4:71-85.

30. Derrickson EM. Comparative reproductive strategies of altricial and precocial eutherian mammals. Funct Ecol. 1992;6:57-65.

31. Schneider NY, Shaw G, Renfree MB. The role of olfaction at birth in marsupial and monotreme mammals. In: East ML, Dehnhard M, editors. Chemical signals in vertebrates 12. New York: Springer; 2013. p. 87-96.

32. Renfree M, Pask A, Shaw G. Reproduction down under: the marsupial mode. Australian Biochemist. 2011;42:16-9.

33. Weisbecker $\vee$, Goswami A. Brain size, life history, and metabolism at the marsupial/ placental dichotomy. Proc Natl Acad Sci U S A. 2010;107:16216-21.

34. Botelho J, Faunes $M$. The evolution of developmental modes in the new avian phylogenetic tree. Evol Dev. 2015;17:221-3.

35. Ligon DJ, Burt DB. Evolutionary origins. In: Koenig WD, Dickinson JL, editors. Cooperative breeding in birds. Cambridge: Cambridge University Press; 2004. p. 5-34.

36. Wang N, Kimball RT. Re-evaluating the distribution of cooperative breeding in birds: is it tightly linked with altriciality? J Avian Biol. 2016:47:724-30.

37. Martin RD, MacLarnon A. Gestaton period, neonatal size and maternal investiment in placental mammals. Nature. 1985:313:220-3.

38. Lemaitre J-F, Müller DWH, Clauss M. A test of the metabolic theory of ecology with two longevity data sets reveals no common cause of scaling in biological times. Mammal Rev. 2014;44:204-14.

39. Clauss M, Dittmann MT, Müller DWH, Zerbe P, Codron D. Low scaling of a life history variable: analysing eutherian gestation periods with and without phylogenty-informed statistics. Mamm Biol. 2014;79:9-16

40. Jackson G, Mooers AØ, Dubman E, Hutchen J, Collard M. Basal metabolic rate and maternal energetic investment durations in mammals. BMC Evol Biol. 2014;a14:194.

41. Müller DWH, Codron D, Werner J, Fritz J, Hummerl J, Griebeler EM, Clauss M. Dichotomy of eutherian reproduction and metabolism. OIKOS. 2012;121:102-15.

42. Bergman TJ, Beehner JC. Measuring social complexity. Anim Behav. 2015; 103:203-9.

43. Burish MJ, Kueh HY, Wang SS-H. Brain architecture and social complexity in modern und ancient birds. Brain Behav Evol. 2004:63:107-24.

44. Iwaniuk AN, Nelson JE, Pellis SM. Do big-brained animals play more? Comparative analyses of play and relative brain size in mammals. J Comp Psychol. 2001;115:24-41.

45. Karlen SJ, Krubitzer L. The functional and anatomical organization of marsupial neocortex: evidence for parallel evolution across mammals. Prog Neurobiol. 2007;82:122-41.

46. Weisbecker V, Blomberg SP, Goldizen AW, Brown M, Fisher D. The evolution of relative brain size in marsupials Is energetically constrained but not driven by behavioral complexity. Brain Behav Evol. 2015;85:125-35.

47. Iwaniuk AN, Nelson JE. Developmental differences are correlated with relative brain size in birds: a comparative analysis. Can J Zool. 2003;81:1913-28.

48. Garamszegi LZ, Biard C, Eens M, Møller AP, Saino N, Surai P. Maternal effects and the evolution of brain size in birds: overlooked developmental constraints. Neurosci Biobehav Rev. 2007;31:498-515.

49. Bennett PM, Harvey PH. Brain size, development and metabolism in birds and mammals. J Zool. 1985;207:491-509.
50. Isler K, van Schaik CP. The expensive brain: A framework for explaining evolutionary changes in brain size. J Hum Evol. 2009b;57:392-400.

51. Isler K, van Schaik CP. Allometric care, life history and brain size evolution in mammals. J Hum Evol. 2012:63:52-63.

52. Clark DA, Mitra PP, Wang SS-H. Scalable architecture in mammalian brains Nature. 2001:411:189-93.

53. Willemet R. Understanding the evolution of mammalian brain structures; the need for a (new) cerebrotype approach. Brain Sci. 2012;2:203-24.

54. Iwaniuk AN, Hurd PL. The evolution of cerebrotypes in birds. Brain Behav Evol. 2005;65:215-30.

55. Isler K, van Schaik CP. Why are there so few smart mammals (but so many smart birds)? Biol Lett. 2009a;5:125-129.

56. Insel TR, Young LJ. Neuropeptides and the evolution of social behavior. Curr Opin Neurobiol. 2000;10:784-9.

57. Ondrasek NR. Emerging frontiers in social neuroendocrinology and the study of nonapeptides. Ethology. 2016;122:1-13.

58. O'Connell LA, Hofmann HA. Genes, hormones, and circuits: an integrative approach to study the evolution of social behavior. Front Neuroendocrinol. 2011;32:320-35

59. Broad KD, Curley JP, Keverne EB. Mother-infant bonding and the evolution of mammalian social relationships. Philos Trans R Soc B. 2006;361:2199-214.

60. Goodson JL, Kelly AM, Kingsbury MA. Nonapeptide mechanisms of gregariousness and social diversity in birds. Horm Behav. 2012;61:239-50.

61. Goodson JL, Schrock SE, Klatt JD, Kabilik D, Kingsbury MA. Mesotocin and nonapeptide receptors promote estrildid flocking behavior. Science. 2009; 325:862-6.

62. Chokchaloemwong D, Prakobsaeng N, Sartsoongnoen N, Kosonsiriluk S, el Halawani ME, Chaiseha Y. Mesotocin and maternal care of chicks in native Thai hens (Gallus domesticus). Horm Behav. 2013;64:53-69.

63. Adkins-Regan E. Hormones and animal social behavior. Princeton: Princeton University Press; 2005.

64. Atkins-Regan E. Neuroendocrinology of social behavior. ILAR J. 2009;50:5-14.

65. Wallen K, Hassett J. Neuroendocrine mechanisms underlying social relationships. In: Ellison PT, Gray PB, editors. Endocrinology of social relationships. Cambridge: Harvard University Press; 2009. p. 32-53.

66. Klatt JD, Goodson JL. Oxytocin-like receptors mediate pair bonding in a socially monogamous songbird. Proc R Soc B. 2013;280:20122396.

67. Carter CS, DeVries AC, Taymans SE, Roberts RL, Williams JR, Getz LL. Peptides, steroids and pairbonds. Ann N Y Acad Sci. 1997;807:260-72.

68. Insel TR, Gingrich BS, Young LH. Oxytocin: who needs it? Prog Brain Res. 2001;133:59-66.

69. Veenema $\mathrm{AH}$, Neumann ID. Central vasopressin and oxytocin release: regulation of complex social behaviours. Prog Brain Res. 2008;170:261-75.

70. Shultz S, Dunbar RIM. The evolution of the social brain: anthropoid primates contrast with other vertebrates. Proc R Soc B. 2007:274:2429-36.

71. van Schaik CP, Aureli F. The natural history of valuable relationships in primates. In: Aureli F, De Waal FBM, editors. Natural conflict resolution. Berkeley: University of California Press; 2000. p. 307-33.

72. Fraser ON, Bugnyar T. The quality of social relationships in ravens. Anim Behav. 2010b;79:927-933.

73. Dunbar RIM. The social brain hypothesis and its implications for social evolution. Ann Hum Biol. 2009;36:562-72.

74. Aureli F, de Waal FBM. Natural conflict resolution. Berkeley: University of California Press; 2000.

75. Olazábal DE, Pereira M, Agrati D, Ferreira A, Fleming AS, Gonzáles-Mariscal G, Levy F, Lucion AB, Morrell Jl, Numan M, Uriarte N. Flexibility and adaptation of the neural substrate that supports maternal behavior in mammals. Neurosci Biobehav Rev. 2013;37:1875-92.

76. Scheiber IBR, Kotrschal K, Weiß BM. The greylag goose as a model for vertebrate social complexity. In: Scheiber IBR, Weiß BM, Hemetsberger J, Kotrschal K, editors. The social life of Greylag Geese: patterns, mechanisms and evolutionary function in an avian model system. Cambridge: Cambridge University Press; 2013. p. 191-201.

77. Fedurek P, Machanda ZP, Schel AM, Slocombe KE. Pant hoot chorusing and social bonds in male chimpanzees. Anim Behav. 2013:86:189-96.

78. Gustison ML, le Roux A, Bergman TJ. Derived vocalizations of geladas (Theropithecus gelada) and the evolution of vocal complexity in primates. Philos Trans R Soc B. 2012;367:1847-59.

79. Evans-Wilent J, Dudzinski KM. Vocalizations associated with pectoral fin contact in bottlenose dolphins (Tursiops truncatus). Behav Processes. 2013;100:74-81.

80. Kulahci IG, Rubenstein DI, Ghazanfar AA. Lemurs groom-at-a distance through vocal networks. Anim Behav. 2015;110:179-86. 
81. Okabe S, Nagasawa M, Mogi K, Kikusui T. The importance of mother-infant communication for social bond formation in mammals. Anim Sci J. 2012;83:446-52.

82. Ziegler TE. Social effects via olfactory sensory stimuli on reproductive function and dysfunction in cooperative breeding marmosets and tamarins. Am J Primatol. 2013;75:202-11.

83. Loretto M-C, Fraser ON, Bugnyar T. Ontogeny of social relations and coalition formation in common ravens (Conus corax). Int J Comp Psychol. 2012;25:180-94.

84. D'Eath RB, Keeling $L$ J. Social discimination and aggression by laying hens in large groups: from peck order to social tolerance. Appl Anim Behav Sci. 2003;84:197-212.

85. Scheiber IBR, Weiß BM, Hirschenhauser K, Wascher CA, Nedelcu IT, Kotrschal $K$. Does 'relationship intelligence' make big brains in birds? Open Access Biol J. 2008;1:6-8.

86. Frigerio D, Weiß BM, Kotrschal K. Spatial proximity among adult siblings in Greylag Geese (Anser anser): evidence for female bonding? Acta Ethologica. 2001;3:121-5.

87. Hacker CE, Horback KM, Miller LJ. GPS technology as a proxy tool for determining relationships in social animals: an example with African elephants. Appl Anim Behav Sci. 2015;163:175-82.

88. Jaatinen K, Jaari S, O'Hara RB, Öst M, Merilä J. Relatedness and spatial proximity as determinants of host-parasite interactions in the brood parasitic Barrow's goldeneye (Bucephala islandica). Mol Ecol. 2009;18:2713-21.

89. Tinsley Johnson E, Snyder-Mackler N, Beehner JC, Bergman TJ. Kinship and dominance rank influence the strength of social bonds in female geladas (Theropithecus gelada). Int J Primatol. 2014;35:288-304.

90. Farine DR, Whitehead H. Constructing, conducting and interpreting animal social network structure. J Anim Ecol. 2015;84:1144-63.

91. Kurvers RHJM, Krause J, Croft DP, Wilson ADM, Wolf M. The evolutionary and ecological consequences of animal social networks: emerging issues. Trends Ecol Evol. 2014;29:326-36.

92. Hamede RK, Bashford J, McCallum H, Jones M. Contact networks in a wild Tasmanian devil (Sarcophilus harrisii) population: using social network analysis to reveal seasonal variability in social behaviour and its implications for transmission of devil facial tumour disease. Ecol Lett. 2009;12:1147-57.

93. Gygax L, Neisen G, Wechsler B. Socio-spatial relationships in dairy cows. Ethology. 2010;116:10-23.

94. Rutz C, Burns Z, James R, Ismar SMH, Burt J, Otis B, Bowen J, St. Clair JJH. Automated mapping of social networks in wild birds. Curr Biol. 2012;22:R669-71.

95. Farine DR. Proximity as a proxy for interactions: issues of scale in social network analysis. Anim Behav. 2015;104:e1-5.

96. Castles M, Heinsohn R, Marshall HH, Lee AEG, Cowlishaw G, Carter AJ. Social networks created with different techniques are not comparable. Anim Behav. 2014;96:59-67.

97. Covas R, Griesser M. Life history and the evolution of family living in birds. Proc R Soc B. 2007;274:1349-57.

98. Drobniak SM, Wagner G, Mourcq E, Griesser M. Family living: an overlooked but pivotal social system to understand the evolution of cooperative breeding. Behav Ecol. 2015;26:805-11.

99. Dugatkin LA. Animal cooperation among unrelated individuals. Naturwissenschaften. 2002;89:533-41.

100. Baglione V, Canestrari D, Marcos JM, Ekman J. Kin selection in cooperative alliances of carrion crows. Science. 2003;300:1947-9.

101. Smith JE, Powning KS, Dawes SE, Estrada JR, Hopper AL, Piotrowski SL, Holekamp KE. Greetings promote cooperation and reinforce social bonds among spotted hyaenas. Anim Behav. 2011;81:401-15.

102. Bertolino S. Herd defensive behaviour of chamois, Rupicapra rupicapra, in response to predation on the young by a golden eagle, Aquila chrysaetos. Jagdwissenschaften. 2003:49:233-6.

103. Micheletta J, Waller BM, Panggur MR, Neumann C, Duboscq J, Agil M, Engelhardt A. Social bonds affect anti-predator behaviour in a tolerant species of macaque, Macaca nigra. Proc R Soc B. 2012;279:4042-50.

104. Hatchwell BJ. The evolution of cooperative breeding in birds: kinship, dispersal and life history. Philos Trans R Soc B. 2009;364:3217-27.

105. Ebensperger LA, Ramirez-Estrada J, Leon C, Castro RA, Ortiz Tolhuysen L, Sobrero R, Quirici V, Burger JR, Soto-Gamboa M, Hayes LD. Sociality, glucocorticoids and direct fitness in the communally rearing rodent, Octodon degus. Horm Behav. 2011;60:346-52.

106. Radford AN. Post-allogrooming reductions in self-directed behaviour are affected by role and status in the green woodhoopoe. Biol Lett. 2012:8:24-7.

107. Lukas D, Clutton-Brock T. Life history and the evolution of cooperative breeding in mammals. Proc R Soc B. 2012a;279:4065-4070.
108. Kingma SA, Santema P, Taborsky M, Komdeur J. Group augmentation and the evolution of cooperation. Trends Ecol Evol. 2014;29:476-84.

109. Riehl C. Evolutionary routes to non-kin cooperative breeding in birds. Proc $R$ Soc B. 2013:280:20132245.

110. Schoepf I, Schradin C. Endocrinology of sociality: comparisons between sociable and solitary individuals within the same population of African striped mice. Horm Behav. 2013;64:89-94.

111. Cordoni G, Palagi E. Reconciliation in wolves (Canis lupus): new evidence for a comparative perspective. Ethology. 2008;114:298-308.

112. Seed AM, Clayton NS, Emery NJ. Postconflict third-party affiliation in rooks, Corvus frugilegus. Curr Biol. 2007;17:152-8.

113. Fraser ON, Bugnyar T. Ravens reconcile after aggressive conflicts with valuable partners. PLoS One. 2011;6:e18118.

114. VanDierendonck MC, de Vries H, Schilder MBH, Colenbrander B, Thorhallsdóttir $A G$, Sigurjónsdóttir $H$. Interventions in social behaviour in a herd of mares and geldings. Appl Anim Behav Sci. 2009;116:67-73.

115. Aureli F, Cords M, Schaik vCP. Conflict resolution following aggression in gregarious animals: a predictive framework. Anim Behav. 2002;64:325-43.

116. Hennessy MB, Kaiser S, Sachser N. Social buffering of the stress response: diversity, mechanisms, and functions. Front Neuroendocrinol. 2009;30:470-82.

117. Scheiber IBR. Tend and be friend': the importance of social allies in coping with social stress. In: Scheiber IBR, Weiß BM, Hemetsberger J, Kotrschal K, editors. The social life of Greylag Geese: patterns, mechanisms and evolutionary function in an avian model system. Cambridge: Cambridge University Press; 2013. p. 156-71.

118. Cockburn A. Prevelance of different modes of parental care in birds. Proc $R$ Soc B. 2006;273:1375-83

119. Langen TA. Prolonged offspring dependence and cooperative breeding in birds. Behav Ecol. 2000;11:367-77.

120. Hale AM. Group living in the black-breasted wood-quail and the use of playbacks as a survey technique. Condor. 2006;108:107-19.

121. Xu Y, Yang N, Zhang K, Yue B, Ran J. Cooperative breeding by buff-throated partridge Tetraophasis szychenyii: a case in the Galliformes. J Ornithol. 2011; 152:695-700.

122. Sherman PT. Social organization of cooperatively polyandrous white-winged trumpeters (Psophia leucoptera). AUK. 1995a;112:296-309.

123. Garnett ST. The social organisation of the dusky moorhen, Gallinula tenebrosa Gould (Aves: Rallidae). Aust Wildl Res. 1980;7:103-12.

124. Sherman PT. Breeding biology of white-winged trumpeters (Psophia leucoptera). in Peru. AUK. 1995b;112:285-295.

125. Lukas D, Clutton-Brock T. Cooperative breeding and monogamy in mammalian societies. Proc R Soc B. 2012b;279:2151-2156.

126. Van Daele PAAG, Faulkes CG, Verheyen $E$, Adriaens D. African mole rats (Bathyergidae): a complex radiation in tropical soils. In: Begall S, Burda $\mathrm{H}$, Schleich CE, editors. Subterranean rodents: news from underground. Berlin: Springer Verlag; 2007. p. 357-73.

127. Bennett NC, Faulkes CG. Life history patterns and reproductive biology: pup development and growth. In: African Mole-Rats: Ecology and Eusociality. Cambridge: Cambridge University Pres; 2000. p. 145-52.

128. Roellig K, Drews B, Goeritz F, Hildebrandt TB. The long gestation of the small naked mole-rat (Heterocephalus glaber RÜPPELL, 1842) studied with ultrasound biomicroscopy and 3D-ultrasonography. PLoS One. 2011;6:e17744.

129. Thornton A, McAuliffe K. Cognitive consequences of cooperative breeding ? A critical appraisal. J Zool. 2015;295:12-22.

130. Kerth G, Perony N, Schweitzer F. Bats are able to maintain long-term social relationships despite the high fission-fusion dynamics of their groups. Proc R Soc B. 2011;278:2761-7.

131. Sewall KB. Social complexity as a driver of communication and cognition. Integr Comp Biol. 2015;55:384-95.

132. Whiten A, Byrne RW. Machiavellian intelligence II: extensions and evaluations. Cambridge: Cambridge University Press; 1997.

133. Byrne RW, Whiten A. Machiavellian intelligence: social expertise, and the evolution of intellect in monkeys, apes, and humans. Oxford: Clarendon; 1988.

134. Moll H, Tomasello M. Cooperation and human cognition: the Vygotskian intelligence hypothesis. Philos Trans R Soc B. 2007;362:639-48.

135. Burkart JM, van Schaik CP. Cognitive consequences of cooperative breeding in primates? Anim Cogn. 2010;13:1-19.

136. Herculano-Houzel S, Collins CE, Wong P, Kaas JH. Cellular scaling rules for primate brains. Proc Natl Acad Sci U S A. 2007;104:3562-7.

137. Reader SM, MacDonald K. Environmental variability and primate behavioural flexibility. In: Reader SM, Laland KN, editors. Animal innovation. Oxford: Oxford University Press; 2002. p. 83-116. 
138. Iwaniuk AN, Arnold KE. Is cooperative breeding associated with bigger brains? A comparative test in the Corvida (Passeriformes). Ethology. 2004;110:203-20.

139. Byrne RW, Bates LA. Sociality, evolution and cognition. Curr Biol. 2007;17: R714-23.

140. Shettleworth SJ. Cognition, evolution and behavior. 2nd ed. New York: Oxford University Press; 2010.

141. Barrett L. Beyond the brain: how body and environment shape animal and human minds. Princeton: Princeton University Press; 2011.

142. Wiley RH. Specificity and multiplicity in the recognition of individuals: implications for the evolution of social behaviour. Biol Rev. 2013;88:179-95.

143. Brosnan SF, Salwiczek L, Bshary R. The interplay of cognition and cooperation. Philos Trans R Soc B. 2010;365:2699-710.

144. Clutton-Brock T. Cooperation between non-kin in animal societies. Nature. 2009;462:51-7.

145. Overduin-de Vries AM, Spruijt BM, de Vries H, Sterck EHM. Tactical deception to hide sexual behaviour: Macaques use distance, not visibility. Behav Ecol Sociobiol. 2014;69:1333-42.

146. Bugnyar T, Kotrschal K. Observational learning and the raiding of food caches in ravens, Corvus corax: is it 'tactical' deception? Anim Behav. 2002; 64:185-95.

147. Taborsky M. Social evolution: reciprocity there is. Curr Biol. 2013;23:R486-8.

148. Tibbetts EA, Dale J. Individual recognition: it is good to be different. Trends Ecol Evol. 2007;22:529-37.

149. Steiger S, Müller JK. 'True' and 'untrue' individual recognition: suggestion of a less restrictive definition. Trends Ecol Evol. 2008;23:355.

150. Beecher MD. Kin recognition in birds. Behav Genet. 1988;18:465-82.

151. Komdeur J, Hatchwell BJ. Kin recognition: function and mechanism in avian societies. Trends Ecol Evol. 1999;14:237-41.

152. Hamilton WD. The genetical evolution of social behavior I. J Theor Biol. 1964a;7:1-16.

153. Hamilton WD. The genetical evolution of social behavior II. J Theor Biol. 1964b; 7:17-52.

154. Cockburn A. Oh sibling, who art thou? Nature. 2010;466:930-1.

155. Krause ET, Krüger $O$, Kohlmeier $P$, Caspers BA. Olfactory kin recognition in a songbird. Biol Lett. 2012;8:327-9.

156. Bateson P. Preference for cousins in Japanese quail. Nature. 1982;295:236-7.

157. Bonadonna F, Sanz-Aguilar A. Kin recognition and inbreeding avoidance: the first evidence for individual kin-related odour recognition. Anim Behav. 2012;84:509-13.

158. Draganoiu TI, Nagle L, Musseau R, Kreutzer M. In a songbird, the black redstart, parents use acoustic cues to discriminate between their different fledglings. Anim Behav. 2006;71:1039-46.

159. Briefer $E$, McElligott AG. Mutual mother-offspring vocal recognition in an ungulate hider species (Capra hircus). Anim Cogn. 2011;14:585-98.

160. Knörnschild M, Feifel M, Kalko EKV. Mother-offspring recognition in the bat Carollia perspicillata. Anim Behav. 2013;86:941-8.

161. Johnson AE, Freedberg S. Variable facial plumage in juvenile cliff swallows: A potential offspring recognition cue? AUK. 2014;131:121-8.

162. Pitcher BJ, Harcourt RG, Schaal B, Charrier I. Social olfaction in marine mammals: wild female Australian sea lions can identify their pup's scent. Biol Lett. 2011;7:60-2.

163. Yoon J, Joo E-J, Yoon H-J, Park H-S, Park S-R. Parent recognition in chicks of the ground-nesting, nidifugous Saunders's gull Saundersilarus saundersi. Acta Ornithologica. 2013;48:245-52.

164. Weiß BM, Schloegl C, Scheiber IBR. How to tell friend from foe: cognition in a complex society. In: Scheiber IBR, Weiß BM, Hemetsberger J, Kotrschal K, editors. The social life of Greylag Geese: patterns, mechanisms and evolutionary function in an avian model system. Cambridge: Cambridge University Press; 2013. p. 172-88.

165. Sibiryakova OV, Volodin IA, Matrosova VA, Volodina EV, Garcia AJ, Gallego L, Landete-Castillejos T. The power of oral and nasal calls to discriminate individual mothers and offspring in red deer, Cervus elaphus. Front Zool. 2015;12:2.

166. Scheiber IBR, Hohnstein A, Kotrschal K, Weiß BM. Juvenile greylag geese (Anser anser) discriminate between individual siblings. PLoS One. 2011;6(8): e22853.

167. Boncoraglio G, Caprioli M, Saino N. Fine-tuned modulation of competitive behaviour according to kinship in barn swallow nestlings. Proc R Soc B. 2009;276:2117-23.

168. Nakagawa S, Waas JR. 'O sibling, where art thou?' - A review of avian sibling recognition with respect to the mammalian literature. Biol Rev. 2004;79:101-19.
169. Hatchwell BJ, Ross DJ, Fowlie MK, McGowan A. Kin discrimination in cooperatively breeding long-tailed tits. Proc R Soc B. 2001:268:885-90.

170. Strickler SA. Recognition of young in a colonially nesting bird. Ethology. 2013:119:130-7.

171. Green JP, Holmes AM, Davidson AJ, Paterson S, Stockley P, Beynon RJ, Hurst $J \mathrm{~L}$. The genetic basis of kin recognition in a cooperatively breeding mammal. Curr Biol. 2015;25:2631-41.

172. Russell AF, Hatchwell BJ. Experimental evidence for kin-biased helping in a cooperatively breeding vertebrate. Proc R Soc B. 2001;268:2169-74.

173. Komdeur J, Richardson DS, Hatchwell BJ. Kin recognition mechanisms in cooperative breeding systems: Ecological causes and behavioural consequences of variation. In: Korb J, Heinze J, editors. Ecology of social evolution. Berlin: Springer Verlag; 2008. p. 175-93.

174. Hatchwell BJ. Cryptic kin selection: kin structure in vertebrate populations and opportunities for kin-directed cooperation. Ethology. 2010;116:203-16

175. Sébe F, Duboscq J, Aubin T, Ligout S, Poindron P. Early vocal recognition of mother by lambs: contribution of low- and high-frequency vocalizations. Anim Behav. 2010;79:1055-66.

176. Dreiss AN, Ruppli CA, Roulin A. Individual vocal signatures in barn owl nestlings: does individual recognition have an adaptive role in sibling vocal competition? J Evol Biol. 2014;27:63-75.

177. Leclaire S, Nielsen JF, Thavarajah NK, Manser MB, Clutton-Brock T. Odourbased kin discrimination in the cooperatively breeding meerkat. Biol Lett. 2013;9:20121054.

178. Petrie M, Krupa A, Burke T. Peacocks lek with relatives even in the absence of social environmental cues. Nature. 1999:401:155-7.

179. Fagot J, Cook RG. Evidence for large long-term memory capacities in baboons and pigeons and its implications for learning and the evolution of cognition. Proc Natl Acad Sci U S A. 2006;103:17564-7.

180. Insley SJ. Long-term vocal recognition in the northern fur seal. Nature. 2000; 406:404-5.

181. Matthews S, Snowdon CT. Long-term memory for calls of relatives in cotton-top tamarins (Saguinus oedipus). J Comp Psychol. 2011;125:366-9.

182. Böckle M, Bugynar T. Long-term memory for affiliates in ravens. Curr Biol. 2012;22:801-6.

183. Pitcher BJ, Harcourt RG, Charrier I. The memory remains: Long-term vocal recognition in Australian sea lions. Anim Cogn. 2010;13:771-6.

184. Briefer E, Padilla de la Torre M, McElligott AG. Mother goats do not forget their kids' calls. Proc R Soc B. 2012;279:3749-55.

185. Hanggi $E B$, Ingersoll JF. Long-term memory for categories and concepts in horses (Equus caballus). Anim Cogn. 2009;12:451-62.

186. Bogale BA, Sugawara S, Sakano K, Tsuda S, Sugita S. Long-term memory of color stimuli in the jungle crow (Corvus macrorhynchos). Anim Cogn. 2012;15:283-91.

187. Weiß BM, Scheiber IBR. Long-term memory of hierarchical relationships in free-living greylag geese. Anim Cogn. 2013;16:91-7.

188. Ueno A, Suzuki K. Comparison of learning ability and memory retention in altricial (Bengalese finch, Lonchura striata var. domestica) and precocial (blue-breated quail, Coturnix chinensis) birds using a color discrimination task. Anim Sci J. 2014;85:186-92.

189. Ophir AG, Galef Jr BG. Female Japanese quail that 'eavesdrop' on fighting males prefer losers to winners. Anim Behav. 2003;66:399-407.

190. McGonigle BO, Chalmers M. Are monkeys logical? Nature. 1977;267:694-6.

191. Vasconcelos M. Transitive inference in non-human animals: an empirical and theoretical analysis. Behav Processes. 2008;78:313-34.

192. Zentall TR, Wassermann EA, Lazareva OF, Thompson RKR, Rattermann MJ. Concept learning in animals. Comp Cogn Behav Rev. 2008;3:1-33.

193. Bond $A B$, Wei $C A$, Kamil AC. Cognitive representation in transitive inference: a comparison of four corvid species. Behav Processes. 2010;85:283-92.

194. Buckner C. Two approaches to the distinction between cognition and 'mere association'. Int J Comp Psychol. 2011;24:314-48.

195. Grosenick L, Clement TS, Fernald RD. Fish can infer rank by observation alone. Nature. 2007:445:429-32.

196. McComb K, Moss CJ, Durant SM, Baker L, Sayialel S. Matriarchs as repositories of social knowledge in African elephants. Science. 2001;292:491-4.

197. Berry PSM, Bercovitch FB. Leadership of herd progressions in the Thornicroft's giraffe of Zambia. Afr J Ecol. 2015;53:175-82.

198. McAuliffe K, Whitehead $\mathrm{H}$. Eusociality, menopause and information in matrilineal whales. Trends Ecol Evol. 2005;20:650.

199. Flack A, Pettit B, Freeman R, Guildford T, Biro D. What are leaders made of? The role of individual experience in determining leader - follower relations in homing pigeons. Anim Behav. 2012;83:703-9. 
200. Mueller T, O'Hara RB, Converse SJ, Urbanek RP, Fagan W. Social learning of migratory performance. Science. 2013;341:999-1002.

201. Nesterova AP, Flack A, van Loon EE, Bonadonna F, Biro D. The effect of experienced individuals on navigation by king penguin chick pairs. Anim Behav. 2015;104:69-78.

202. Bousquet $\mathrm{CAH}$, Manser MB. Resolution of experimentally induced symmetrical conflicts of interests in meerkats. Anim Behav. 2011;81:1101-7.

203. Fritz J, Bisenberger A, Kotrschal K. Stimulus enhancement in greylag geese: socially mediated learning of an operant task. Anim Behav. 2000;59:1119-25.

204. Bro-Jørgensen J, Pangle WM. Male topi antelopes alarm snort deceptively to retain females for mating. Am Nat. 2010;176:E33-9.

205. Bugnyar T. Social cognition in ravens. Comp Cogn Behav Rev. 2013:8:1-12.

206. Flower TP, Gribble M, Ridley AR. Deception by flexible alarm mimicry in an African bird. Science. 2014;344:513-6.

207. le Roux A, Snyder-Mackler N, Roberts EK, Beehner JC, Bergman TJ. Evidence for tactical concealment in a wild primate. Nat Commun. 2013;4:1462.

208. Wheeler BC. Monkeys crying wolf? Tufted capuchin monkeys use anti-predator calls to usurp resources from conspecifics. Proc R Soc B. 2009;276:3013-8.

209. Riehl C, Frederickson ME. Cheating and punishment in cooperative animal societies. Philos Trans R Soc B. 2016;371:20150090.

210. Pennisi E. Social animals prove their smarts. Science. 2006:312:1734-8.

211. Gehrt SD, Fritzell EK. Duration of familial bonds and dispersal patterns for raccoons in South Texas. J Mammal. 1998:79:859-72.

212. Archie EA, Tung J, Clark M, Altmann J, Alberts SC. Social affiliation matters: both same-sex and opposite relationships predict survival in wild female baboons. Proc R Soc B. 2014;281:20141261.

213. Rosenbaum S, Hirwa JP, Silk JB, Stoinski TS. Relationships between adult male and maturing mountain gorillas (Gorilla beringei beringei) persist across developmental stages and social upheavel. Ethology. 2016;122:134-50.

214. Gero S, Gordon J, Whitehead H. Individualized social preferences and long-term social fidelity between social units of sperm whales. Anim Behav. 2015;102:15-23.

215. Mann J, Connor RC, Tyack PL, Whitehead H. Cetacean societies: field studies of dolphins and whales. Chicago: The University of Chicago Press; 2000.

216. Wittemyer G, Douglas-Hamilton I, Getz WM. The socioecology of elephants: analysis of the processes creating multitiered social structures. Anim Behav. 2005:69:1357-71.

217. Wittemyer G, Okelio JBA, Rasmussen HB, Arctander P, Nyakaana S, Douglas-Hamilton I, Siegismund HR. Where sociality and relatedness diverge: the genetic basis for hierarchical social organization in African elephants. Proc R Soc B. 2009;276:3513-21.

218. Focardi S, Morimando F, Capriotti S, Ahmed A, Genov P. Cooperation improves the access of wild boards (Sus scrofa) to food sources. Behav Processes. 2015;121:80-6.

219. Braun A, Bugnyar T. Social bonds and rank acquisition in raven nonbreeder aggregations. Anim Behav. 2012;84:1507-15.

220. Pika S, Bugnyar T. The use of referential gestures in ravens (Corvus corax) in the wild. Nat Commun. 2011;2:560.

221. Bird CD. Rooks perceive support relations similar to six-month-old babies. Proc R Soc B. 2010;277:147-51.

222. Scheiber IBR, Kotrschal K, Weiß BM. Benefits of family reunions: Social support in secondary greylag goose families. Horm Behav. 2009a;55:133-138.

223. Black JM, Owen M. Parent-offspring relationship in wintering barnacle geese. Anim Behav. 1989;37:187-98

224. Lehmann J, Boesch C. Sociality of the dispersing sex: the nature of social bonds in West African female chimpanzees, Pan troglodytes. Anim Behav. 2009;77:377-87.

225. Mitani JC. Male chimpanzees form enduring and equitable social bonds. Anim Behav. 2009;77:633-40.

226. Cameron EZ, Setsaas TH, Linklater Wayne L. Social bonds between unrelated females increase reproductive success in feral horses. Proc Natl Acad Sci U S A. 2009;106:13850-3.

227. Carter K, Brand R, Carter JK, Shorrocks B, Goldizen AW. Social networks, long-term associations and age-related sociability in wild giraffes. Anim Behav. 2013:86:901-10

228. McDonald DB. Young-boy networks without kin clusters in a lek-mating manakin. Behav Ecol Sociobiol. 2009;63:1029-34.

229. Edelman AJ, McDonald DB. Structure of male cooperation networks at longtailed manakin leks. Anim Behav. 2014;97:125-33.

230. Young LC, Zaun BJ, VanderWerf EA. Successful same-sex pairing in Laysan albatross. Biol Lett. 2008:4:323-5.

231. MacFarlane GR, Blomberg SP, Vasey PL. Homosexual behaviour in birds: frequency of expression is related to parental care disparity between the sexes. Anim Behav. 2010;80:375-90.
232. Huber R, Martys M. Male-male pairs in greylag geese (Anser anser). J Ornithol. 1993:134:155-64.

233. Kotrschal K, Hemetsberger J, Weiß BM. Making the best of a bad situation: homosociality in male greylag geese. In: Vasey P, Sommer V, editors. Homosexual behaviour in animals: an evolutionary perspective. Cambridge: Cambridge University Press; 2006. p. 45-76.

234. Newton-Fisher NE, Lee P. Grooming reciprocity in wild male chimpanzees. Anim Behav. 2011:81:439-46.

235. Manno TG. Social networking in the Columbian ground squirrel, Spermophilus columbianus. Anim Behav. 2008;75:1221-8.

236. Freeman NJ, Young C, Barrett L, Henzi P. Coalition formation by male vervet monkeys (Chlorocebus pygerythrus) in South Africa. Ethology. 2016;122:45-52.

237. Snyder-Mackler N, Kohn JN, Barreiro LB, Johnson ZP, Wilson ME, Tung J. Social status drives social relationships in groups of unrelated female rhesus macaques. Anim Behav. 2016;111:307-17.

238. Val-Laillet D, Guesdon V, von Keyserlingk MAG, de Passillé AM, Rushen J. Allogrooming in cattle: relationships between social preferences, feeding displacements and social dominance. Appl Anim Behav Sci. 2011;116:141-9.

239. Feh C, Mazieres J. Grooming at a preferred site reduces heart rate in horses. Anim Behav. 1993;46:1191-4.

240. Stöwe M, Bugnyar T, Schloegl C, Heinrich B, Kotrschal K, Möstl E. Corticosterone excretion patterns and affiliative behavior over development in ravens (Corvus corax). Horm Behav. 2008;53:208-16.

241. Lewis S, Roberts G, Harris MP, Prigmore C, Wanless S. Fitness increases with partner and neighbour allopreening. Biol Lett. 2007;3:386-9.

242. Stevens JR, Gilby IC. A conceptual framework for nonkin food sharing: timing and currency of benefits. Anim Behav. 2004;67:603-14.

243. de Kort SM, Emery NJ, Clayton NS. Food sharing in jackdaws, Corvus monedula, what, why and with whom? Anim Behav. 2006;72:297-304.

244. von Bayern AMP, de Kort SM, Clayton NS, Emery NJ. The role of food- and object-sharing in the development of social bonds in juvenile jackdaws (Corvus monedula). Behaviour. 2007;144:711-33.

245. Senar JC. Allofeeding in Eurasian siskins (Carduelis spinus). Condor. 1984;86:213-4.

246. Brown CR, Brown MB, Shaffer ML. Food-sharing signals among socially foraging cliff swallows. Anim Behav. 1991;42:551-64.

247. Kalishov A, Zahavi A, Zahavi A. Allofeeding in Arabian babblers (Turdoides squamiceps). J Ornithol. 2005;146:141-50.

248. Lorenz K. Here i am - where are you? New York: Hartcourt Brace Jovanovich; 1991.

249. Kurvers RHJM, Adamczyk VMAP, Kraus RHS, Hoffman JI, van Wieren SE, van der Jeugd HP, Amos W, Prins HHT, Jonker RM. Contrasting context dependence of familiarity and kinship in social networks. Anim Behav. 2013;86:993-1001.

250. Cantor $M$, Whitehead $\mathrm{H}$. How does social behavior differ among sperm whale clans? Mar Mamm Sci. 2015:31:1275-90.

251. Connor RC, Smolker R, Bejder L. Synchrony, social behaviour and alliance affiliation in Indian ocean bottlenose dolphins, Tursiops aduncus. Anim Behav. 2006;72:1371-8.

252. Spoon TR, Millam JR, Owings DH. The importance of mate behavioural compatibility in parenting and reproductive success by cockatiels, Nymphicus hollandicus. Anim Behav. 2006;71:315-26.

253. Nedelcu IT, Hirschenhauser K. Maintenance of the monogamous pair bond. In: Scheiber IBR, Weiß BM, Hemetsberger J, Kotrschal K, editors. The social life of Greylag Geese: patterns, mechanisms and evolutionary function in an avian model system. Cambridge: Cambridge University Press; 2013. p. 65-87.

254. Eklund B, Jensen P. Domestication effects on behavioural synchronization and individual distances in chickens (Gallus gallus). Behav Processes. 2011;86:250-6.

255. Silk JB, Cheney DL, Seyfarth RM. A practical guide to the study of social relationships. Evol Anthr. 2013;22:213-25.

256. Biondo C, Ozar P, Miyaki CY, Bussab VSR. Social structure of collared peccaries (Pecari tajacu): does relatedness matter? Behav Processes. 2014;109:70-8.

257. Stanley CR, Dunbar RIM. Consistent social structure and optimal clique size revealed by social network analysis. Animal Behaviour. 2013;85.

258. Smith JE, Van Horn RC, Powning KS, Cole AR, Graham KE, Memenis SK, Holekamp KE. Evolutionary forces favoring intragroup coalitions among spotted hyenas and other animals. Behav Ecol. 2010;21:284-303.

259. Engh AL, Siebert ER, Greenberg DA, Holekamp KE. Patterns of alliance formation and postconflict aggression indicate spotted hyaenas recognize third party relationships. Anim Behav. 2005:69:209-17.

260. Fraser ON, Bugnyar T. Reciprocity of agonistic support in ravens. Anim Behav. 2012:83:171-7.

261. Scheiber IBR, Kotrschal K, Weiß BM. Serial agonistic attacks by greylag goose families (Anser anser) against the same opponent. Anim Behav. 2009b;77: 1211-1216. 
262. Scheiber IBR, Weiß BM, Frigerio D, Kotrschal K. Active and passive social support in families of Greylag Geese (Anser anser). Behaviour. 2005;142:1535-57.

263. Scott DK. Functional aspects of prolonged parental care in Bewick's swans. Anim Behav. 1980;28:938-52.

264. Öst M, Vitikainen E, Waldeck P, Sundström L, Lindström K, Hollmen T, Franson C, Kilpi M. Eider females form non-kin brood-rearing coalitions. Mol Ecol. 2005;14:3903-8.

265. Arroyo B, Francois M, Bretagnolle V. Colonioal breeding and nest defence in Montagu's harrier (Circus pygargus). Behav Ecol Sociobiol. 2001;50:109-15.

266. Stenhouse IJ, Gilchrist HG, Montevecchi WA. An experimental study ecamining the anti-predator behaviour of Sabine's gull (Xema sabini) during breeding. J Ethol. 2005;23:103-8.

267. Fox AD, Boyd H, Bromley RG. Mutual benefits of associations between breeding and non-breeding White-fronted Geese, Anser albifrons. Ibis. 1995;137:151-6.

268. Solomon NG, French JA. Cooperative breeding in mammals. Cambridge: Cambridge University Press; 2007.

269. Koenig WD, Dickinson JL. Ecology and evolution of cooperativve breeding in birds. Cambridge: University of Cambridge Press; 2004.

270. McRae SB. Family values: costs and benefits of communal nesting in the moorhen. Anim Behav. 1996:52:225-45.

271. Craig JL. Pair and group breeding behaviour in the communal gallinule, the pukeko, Porphyrio porphyrio melanotus. Anim Behav. 1980;28:593-603.

272. Wahaj S, Guse KR, Holecamp KE. Reconciliation in the spotted hyena (Crocuta crocuta). Ethology. 2001;107:1057-74

273. Kutsukake N, Clutton-Brock T. Do meerkats engage in a conflict management following aggression? Reconciliation, submission and avoidance. Anim Behav. 2008;75:1441-53.

274. Das M. Conflict management via third parties. In: Aureli F, De Waal FBM, editors. Natural conflict resolution. Berkeley: University of California Press; 2000. p. 263-80.

275. Watts DP, Comenares F, Arnold K. Redirection, consolation, and policing. In: Aureli F, De Waal FBM, editors. Natural conflict resolution. Berkeley: University of California Press; 2000. p. 281-301.

276. Yamamoto C, Morisaka T, Furuta K, Ishibashi T, VYoshida A, Taki M, Yoshihisa M, Amano M. Post-conflict affiliation as conflict management in captive bottlenose dolphins (Tursiops truncatus). Sci Rep. 2015;5:14275.

277. Cozzi A, Sighieri C, Gazzano A, Nicol CJ, Baragli P. Post-conflict friendly reunion in a permanent group of horses (Equus caballus). Behav Processes. 2010;85:185-90.

278. Fraser ON, Bugnyar T. Do ravens show consolation? Responses to distressed others. PloS One. 2010a;5:e10605.

279. Young C, Majolo B, Heistermann M, Schülke O, Ostner J. Responses to social and environmental stress are attenuated by strong male bonds in wild macaques. Proc Natl Acad Sci U S A. 2014;111:18195-200.

280. Kiyokawa Y, Hiroshima S, Takeuchi Z, Mori Y. Social buffering reduces male rats' behavioral and corticosterone responses to a conditioned stimulus. Horm Behav. 2014;65:114-8.

281. Reimert I, Bolhuis JE, Kemp B, Rodenburg TB. Social support in pigs with different coping styles. Physiol Behav. 2014;129:221-9.

282. Hennessy MB, Neisen G, Bullinger KL, Kaiser S, Sachser N. Social organization predicts nature of infant-adult interactions it two species of wild guinea pigs (Cavia aperea and Galea monasteriensis). J Comp Psychol. 2006;120:12-8.

283. Edgar J, Held S, Paul E, Pettersson I, I'Anson Price R, Nicol CJ. Social buffering in a bird. Anim Behav. 2015;105:11-9.

284. Li Q, Zhang L. Parent-offspring recognition in Brandt's voles, Lasiopodomys brandti. Anim Behav. 2010;79:797-801.

285. Wanker R. Socialization in spectacled parrotlets (Forpus conspicillatus): how juveniles compensate for the lack of siblings. Acta Ethologica. 1999;2:23-8.

286. Mulard H, Danchin E. The role of parent-offspring interactions during and after fledging in the black-legged kittiwake. Behav Processes. 2008;79:1-6.

287. Kraaijeveld K. Black Swans Cygnus atratus adopt related cygnets. Ardea. 2005;93:163-9.

288. Sieber OJ. Acoustic recognition between mother and cubs in raccoons (Procyon lotor). Behaviour. 1986;96:130-62.

289. Torriani MVG, Vannoni E, McElligott AG. Mother - young recognition in an ungulate hider species: a unidirectional process. Am Nat. 2006;168:412-20.

290. McDonald PGM, Wright J. Bell miner provisioning calls are more similar among relatives and are used by helpers at the nest to bias their effort towards kin. Proc R Soc B. 2011;278:3403-11.

291. Wahaj S, Van Horn RC, Van Horn TL, Dreyer R, Hilgris R, Schwarz J, Holecamp KE. Kin discrimination in the spotted hyena (Crocuta crocuta): nepotism among siblings. Behav Ecol Sociobiol. 2004;56:237-47.
292. Sun L, Müller-Schwarze D. Sibling recognition in the beaver: a field test for phenotype matching. Anim Behav. 1997;54:493-502.

293. Wanker R, Apcin J, Jennerjahn B, Waibel B. Discrimination of different social companions in spectacled parrotlets (Forpus conspicillatus): evidence for individual vocal recognition. Behav Ecol Sociobiol. 1998;43:197-202.

294. Mateo JM. Kin recognition in ground squirrels and other rodents. J Mammal. 2003;84:1163-81.

295. Porter $\mathrm{RH}$. The ontogeny of sibling recognition in rodents: Superfamily Muroidea. Behav Genet. 1988;18:483-94.

296. Burley N, Minor C, Strachan C. Social preference of zebra finches for siblings, cousins and non-kin. Anim Behav. 1990;39.

297. Ceacero F, Landete-Castillejos T, Garcia AJ, Estevez JA, Gallego L. Kinship discrimination and effects on social ranks and aggressiveness levels in Iberian red deer hinds. Ethology. 2007;113:1133-40.

298. Griesser M, Halvarsson P, Drobniak SM, Vilà C. Fine-scale kin recognition in the absence of social familiarity in the Siberian jay, a monogamous bird species. Mol Ecol. 2015;24:5726-38.

299. Krakauer AH. Kin selection and cooperative courtship in wild turkeys. Nature. 2005:434:69-72.

300. Sharpe LL, Hill A, Cherry MI. Individual recognition in a wild cooperative mammal using contact calls. Anim Behav. 2013;86:893-900.

301. Bates LA, Sayialel KN, Njiraini NW, Poole JH, Moss CJ, Byrne RW. African elephants have expectations about the locations of out-of-sight family members. Biol Lett. 2008;4:34-6.

302. Proops L, McComb K, Reby D. Cross-modal individual recognition in domestic horses (Equus caballus). Proc Natl Acad Sci U S A. 2009;106:947-51.

303. Levréro F, Durand L, Vignal C, Blanc A, Mahtevon N. Begging calls support offspring individual identity and recognition by zebra finch parents. C R Biol. 2009:332:579-89.

304. Paxton R, Basile BM, Adachi I, Szuzuki WA, Wilson ME, Hampton RR. Rhesus monkeys (Macaca mulatta) rapidly learn to select dominant individuals in videos of artificial social interactions between unfamiliar conspecifics. J Comp Psychol. 2010:124:395-401.

305. Silverman JL, Gastrell PT, Karras MN, Solomon M, Crawley JN. Cognitive abilities on transitive inference using a novel touchscreen technology for mice. Cereb Cortex. 2015;25:1133-42.

306. Tromp D, Meunier $\mathrm{H}$, Roeder JJ. Transitive inference in two lemur species (Eulemur macaco and Eulemur fulvus). Am J Primatol. 2015;77:338-45.

307. Mikolasch S, Kotrschal K, Schloegl C. Transitive inference in jackdaws (Corvus monedula). Behav Processes. 2013;92:113-7.

308. Scarf D, Colombo M. Representation of serial order in pigeons (Columba livia). J Exp Psychol Anim Behav Process. 2010;36:423-9.

309. Paz-Y-Mino G, Bond AB, Kamil AC, Balda RP. Pinyon Jays use transitive inference to predict social dominance. Nature. 2004;430:778-81.

310. Hogue M-E, Beaugrand JP, Lague PC. Coherent use of information by hens observing their former dominant defeating or being defeated by a stranger. Behav Processes. 1996;38:241-52.

311. Weiß BM, Kehmeier S, Schloegl C. Transitive inference in free-living greylag geese, Anser anser. Anim Behav. 2010;79:1277-83.

312. Daisley JN, Valiortigara G, Regolin L. Logic in an asymmetrical (social) brain: transitive inference in the young domestic chick. Soc Neurosci. 2010;5:309-19.

313. Watts HE, Holekamp KE. Hyena societies. Curr Biol. 2007;17:R657-60.

314. Ward C, Trisko R, Smuts BB. Third-party interventions in dyadic play between littermates of domestic dogs, Canis lupus familiaris. Anim Behav. 2009;78:1153-60.

315. Wittig RM, Crockford C, Langergraber KE, Zuberbühler K. Triadic social interactions operate across time: a field experiment with wild chimpanzees. Proc R Soc B. 2014:281:20133155.

316. Jennings DJ, Carlin C, Hayden TJ, Gammell MP. Third-party intervention behaviour during fallow deer fights: the role of dominance, age, fighting and body size. Anim Behav. 2011;81:1217-22.

317. Krueger K, Schneider G, Flauger B, Heinze J. Context-dependent third-party intervention in agonistic encounters of male Przewalski horses. Behav Processes. 2015:121:54-62

318. Wascher CAF, Scheiber IBR, Weiß BM, Kotrschal K. Heart rate responses to agonistic encounters in greylag geese, Anser anser. Anim Behav. 2009;77:955-61

319. Keverne EB, Nevison CM, Martel FL. Early learning and the social bond. Ann N Y Acad Sci. 1997;807:329-39. 
320. Oostindjer M, Bolhuis JE, Mendl M, Held S, van den Brand H, Kemp B. Learning how to eat like a pig: effectiveness of mechanisms for vertical social learning in piglets. Anim Behav. 2011;82:503-11.

321. McComb K, Greaeme S, Durant SM, Sayialel KN, Slotow RH, Poole JH, Moss

CJ. Leadership in African elephants: the adaptive value of age. Proc R Soc B. 2011;278:3270-6.

Submit your next manuscript to BioMed Central and we will help you at every step:

- We accept pre-submission inquiries

- Our selector tool helps you to find the most relevant journal

- We provide round the clock customer support

- Convenient online submission

- Thorough peer review

- Inclusion in PubMed and all major indexing services

- Maximum visibility for your research

Submit your manuscript at www.biomedcentral.com/submit 